\title{
Differential Effects of Glycosaminoglycans on Neurite Growth on Laminin and L1 Substrates
}

\author{
Chang-Lin Dou and Joel M. Levine \\ Department of Neurobiology and Behavior, State University of New York at Stony Brook, Stony Brook, New York \\ 11794
}

Glycosaminoglycans (GAGs), the carbohydrate moieties of proteoglycans, are thought to be positive and negative regulators of axonal growth. The physiological role of GAGs is controversial as some studies have shown that GAGs inhibit cell adhesion and neurite elongation (Exp Neurol $109: 111,1990)$ whereas other studies have reported a growth stimulatory effect of GAGs (Development 114:17, 1992). These and other studies have examined the effects of GAGs using different types of neurons and different substrate conditions thereby making a direct comparison of the experimental data difficult. To resolve the controversy concerning the ability of exogenous GAGs to modulate neurite growth, we examined the effects of a panel of structurally different GAGs on the growth of postnatal rat cerebellar granule neurons and embryonic rat dorsal root ganglia (DRG) neurons on substrates of either laminin or the L1 glycoprotein. Here we show that chondroitin 4-sulfate (CS4), chondroitin 6-sulfate (CS6), and keratan sulfate (KS) inhibit neurite growth from both cerebellar and DRG neurons on laminin-coated surfaces. On L1 surfaces, however, these GAGs are either extremely weak inhibitors of neurite extension or, in the case of CS4, a modest stimulator of neurite growth. Heparan sulfate (HS) and dermatan sulfate (DS) inhibited the growth of cerebellar neurons but not the growth of DRG neurons on L1-coated surfaces. On laminin surfaces, DS and HS had no effect on neurite growth from both cerebellar and DRG neurons. These results demonstrate a cellular and a substrate specificity to the effects of exogenous GAGs on neurite extension in vitro. They suggest that while CS and KS GAGs may not exert strong negative influences over axonal growth in regions of the developing CNS where the L1 glycoprotein is abundant, these GAGs are capable of inhibiting the growth of axons that extend within an environment rich in laminin.

[Key words: glycosaminoglycan, proteoglycan, cell adhesion molecule, axonal growth, Iaminin, L1]

To find their appropriate target cells, the axons of developing neurons navigate through a complex terrain composed of other neurons, glial cells, and extracellular matrix (ECM) components.

Received May 22, 1995; revised Aug. 2, 1995; accepted Aug. 14, 1995.

We thank Dr. V.Lemmon for his gift of antibodies, Dr. S. Halegoua for his gift of NGF and Dr. S. Scott for her comments on the manuscript. This work was supported by NIH Grant NS21198 and by a grant from the Center for Biotechnology, SUNY at Stony Brook, which is sponsored by the New York State Science and Technology Foundation.

Correspondence should be addressed to Joel M. Levine at the above address. Copyright (C) 1995 Society for Neuroscience $0270-6474 / 95 / 158053-14 \$ 05.00 / 0$
This complex terrain is likely to contain the information that guides growing axons to their appropriate postsynaptic targets (for review, see Goodman and Shatz, 1993). At least some of this information is encoded by (1) target-derived chemoattractants (Kennedy et al., 1994; Serafini et al., 1994) and repellents (Fitzgerald et al., 1993; Pini, 1993; Colamarino and Tessier-Lavigne, 1995), (2) cell adhesion molecules and ECM components that are permissive for axon growth (Rutishauser and Jessell, 1988; Sanes, 1989), and (3) extracellular and cell surface molecules that inhibit neurite growth (reviewed by Patterson, 1988; Keynes and Cook, 1995). By integrating these diverse environmental signals, growth cones are able to find their appropriate target cells with precision and reproducibility.

A large number of molecules can provide a positive substrate for neurite extension in vitro. These neurite growth-promoting molecules include ECM-associated molecules such as laminin (Sanes, 1989) and multiple members of the immunoglobulin super family of cell adhesion molecules or CAMs such as I.1(NII.F), G4, and TAG1 (Lemmon et al., 1989; Furley et al., 1990; Kuhn et al., 1990). CAMs such as L1 are thought to act primarily through homophilic binding mechanisms (Lemmon et al., 1989), although heterophilic interactions among different CAMs can also occur (Kadmon et al., 1990a,b; Kuhn et al., 1990; Felsenfeld et al., 1994). CAMs and the cellular receptors for ECM components are linked to intracellular second messenger systems whose activation is prerequisite for neurite extension (Bixby, 1989; Schuch et al., 1989; Walsh and Doherty, 1992). While CAMs have a potent ability to promote neurite elongation in vitro, these molecules, with the exception of TAGl (Dodd et al., 1988), are not distributed in a manner that delineates specific axonal pathways in vivo (Faissner et al., 1984; Stallcup et al., 1985; Rutishauser and Jessell, 1988). Thus, ECM-associated molecules and CAMs can be considered as generally permissive for axonal extension (Lemmon et al., 1992) and these molecules alone cannot explain fully the specificity with which growing axons find their target cells.

Molecules with the ability to inhibit axonal extension in vitro include numerous proteins (Lochter et al., 1991; Kolodkin et al., 1993; Luo et al., 1993), glycoproteins (Caroni and Schwab, 1988; Davies et al., 1990) and proteoglycans (Snow et al., 1990a; Cole and McCabe, 1991; Oohira et al., 1991; Geisert and Bidanset, 1993; Dou and Levine, 1994; Friedlander et al., 1994). As is the case with CAMs, some of these growth inhibitory molecules share structural features and comprise a molecular family known as semaphorins (Kolodkin et al., 1993; Luo et al., 1993). These molecules participate in the guidance of growing axons to their targets by defining areas of the nervous system that are nonpermissive for axonal growth (Patterson, 1988). 
Proteoglycans are multifunctional macromolecules comprising a core polypeptide and covalently attached glycosaminoglycan (GAG) chains (for review, see Jackson et al., 1991; Hardingham and Fosang, 1992). The physiological functions of GAGs in the developing nervous system are controversial. The observations that exogenous GAGs inhibit cell attachment and neurite growth (Carbonetto et al., 1983; Akeson and Warren, 1986; Snow et al., 1990a) and that GAGs are responsible for the neurite growth inhibitory effects of some brain proteoglycans (Cole and McCabe, 1991; Geisert and Bidanset, 1993) suggest that these carbohydrate polymers may be endogenous inhibitors of axonal extension. Other studies, however, have shown that the GAG chains are not required for the inhibitory actions of other proteoglycans of the nervous system (Oohira et al., 1991; Grumet el al., 1993; Dou and Levine, 1994). The physiological relevance of the negative effects of GAGs on neurite extension in vitro is further brought into question by the observation that thalamocortical axons extend within the chondroitin sulfate rich subplate of the developing telencephalon (Bicknese et al., 1994).

Variations in the types of neurons and the types of substrates tested in the studies cited above make a direct comparison of the experimental results difficult. Therefore, we studied the effects of a panel of different GAGs on axonal growth from two populations of developing neurons, cerebellar granule cells and dorsal root ganglia (DRG) neurons. The effects of individual GAGs were tested in the presence of either laminin or the L1 glycoprotein. The results presented here demonstrate that the effects of GAGs on neurite extension are complex and vary according to other components of the substrate and according to neuronal type. Our data infer that GAGs, with the exception of IIS, may play only a minor role as inhibitors of neurite growth within those areas of the developing CNS where the L1 glycoprotein is ahundant (Faissner et al., 1984; Stallcup et al., 1985); however, GAGs may exert strong inhibitory influences over the growth of neurons in an environment where laminin predominates.

\section{Materials and Methods}

Materials. Monoclonal antibody $74-5 \mathrm{H} 7$ against $\mathrm{L} 1$ was generously provided by Dr. V. Lemmon (Lemmon et al., 1989). Poly-L-lysine (PI.J.), phenyl methyl-sulfonylfluoride (PMSF), $N$-ethyl maleimide (NEM), leupeptin, chondroitin 6-sulfate (chondroitin sulfate $C$ ), heparan sulfate, dermatan sulfate, monoclonal antibody CS-56 (Avnur and Geiger, 1984), Sigma 104 phosphatase substrate, normal rabbit serum, and rabbit anti-mouse IgG antiserum were bought from Sigma (St. Louis, MO). Alkaline phosphatase conjugated goat anti-mouse IgG was purchased from Fisher (Pittsburgh, PA); Pansorbin cells and chondroitin 4-sulfate (chondroitin sulfate A) from Calbiochem (San Diego, CA). Proteasefree chondroitinase $A B C$ and quick spin protein columns were procured from Boehringer Mannheim (Indianapolis, IN); keratan sulfate and keratanase from Seikagaku America Inc. (Rockville, MD); collagenase from GIBCO (Grand Island, NY) and trypsin from Worthington (Freehold, NJ). Laminin, basic fibroblast growth factor (bFGF), and monoclonal anti-laminin B1 chain antibody were obtained from Ipstate Biotechnology Inc. (Lake Placid, NY); lithium 3,5-diiodosalicylate (LIS) from Eastman Kodak Company (Rochester, NY); protein assay kit (Bradford) and Tween 20 from Bio Rad (Richmond, CA); and 18- and 96-well tissue culture plates from Costar (Cambridge, MA). SpragueDawley rats were maintained and bred in the University animal facility.

Imrrunoaffinity purification of $L 1$. The $\mathrm{L} 1$ glycoprotein was purified from postnatal day 6 rat brain membranes using a solid phase immunoabsorbent technique (MacSween and Eastwood, 1978) as described previously (Dou and Levine, 1994). For each preparation, the purified material was subjected to SDS-PAGE under reducing conditions to monitor the purity and yield of the L.1 glycoprotein.

Substrate preparation and characterization. Forty-eight well tissue culture plates were coated with $25 \mu \mathrm{g} / \mathrm{ml}$ of PLL overnight followed by either $\mathrm{L} 1$ or laminin, both at $2 \mu \mathrm{g} / \mathrm{ml}$, or a mixture of the same amount of $\mathrm{L} 1$ or laminin and $1-1000 \mu \mathrm{g} / \mathrm{ml}$ of various GAGs for $3 \mathrm{hr}$ at $37^{\circ} \mathrm{C}$. The surfaces were washed with PBS before seeding of the neurons. Previous studies (Dou and Levine, 1994) employing 125I-labeled laminin or $\mathrm{L} 1$ established that $65 \%$ of the input laminin and $80 \%$ of the input L1 bound to the PLL-coated surfaces. A previous dose response analysis (Dou and Levine, 1994) also showed that when surfaces are coated with laminin or L1 at a concentration of $2 \mu \mathrm{g} / \mathrm{ml}$, the mean neurite length was $90 \%$ of the maximal length obtained with higher concentrations of these proteins.

To determine the amount of chondroitin sulfate GAGs, laminin and the L1 glycoprotein that had bound to the substrates, we used solid phase ELISA assays. Ninety-six well culture plates were coated with PLL $(25 \mu \mathrm{g} / \mathrm{ml})$ overnight followed by either pure GAGs, the neuritepromoting proteins or mixtures of the GAGs and the neurite-promoting proteins for $3 \mathrm{hr}$ at $37^{\circ} \mathrm{C}$. The surfaces were then blocked with blotto (5\% nonfat dry milk, $0.05 \%$ Tween 20 in PBS) for $1 \mathrm{hr}$ at room temperature (RT) followed by incubation with the antibodies described below. After three washes with PBS plus $0.5 \%$ Tween 20, the plates were incubated with alkaline phosphatase-linked goat anti-mouse IgG (1:500) for $1 \mathrm{hr}$. After 3 more washes, $50 \mu \mathrm{l}$ of freshly prepared substrate mixture $(1 \mathrm{mg} / \mathrm{ml}$ of Sigma 104 phosphatase substrate in $100 \mathrm{mmM}$ Tris$\mathrm{HCl}, \mathrm{pH} 9.5,100 \mathrm{mM} \mathrm{NaCl}, 5 \mathrm{mM} \mathrm{MgCl}_{2}$ ) was added to each well for 5-40 min depending on the speed of color reaction. The color development was stopped by adding $50 \mu \mathrm{l} /$ well of $0.1 \mathrm{M}$ EDTA, $\mathrm{pH} 7.5$, and the plate was read at $405 \mathrm{~nm}$ using an ELISA reader. PLL wells without antigen served as blanks and the reading from the no antigen wells incubated with antibodies was subtracted to exclude any nonspecific binding of antibodies to the tissue culture surfaces.

To measure substrate-bound CS4 and CS6, we used monoclonal antibody CS-56 which recognizes both CS4 and CS6 (Avnur and Geiger, 1984). Since the antibody has a higher avidity for CS6 than for CS4 (Avnur and Geiger, 1984), we used it at $4 \mu \mathrm{g} / \mathrm{ml}$ for CS4 and $400 \mathrm{ng}$ / $\mathrm{ml}$ for CS6. The $\mathrm{L} 1$ glycoprotein was detected with monoclonal antibody $74-5 \mathrm{H} 7$ (Lemmon et al., 1989), at a concentration of $200 \mathrm{ng} / \mathrm{ml}$, and laminin was detected with a monoclonal antibody directed against the $\mathrm{B} 1$ chains used at $1 \mu \mathrm{g} / \mathrm{ml}$. In all cases, the antibodies were tested against their respective antigens over a wide range of concentrations to ensure that the antibody responses were in the linear range. All experiments comprised duplicate or tetraplicate wells and were repeated two or three times each.

Enzymatic treatment of the glycosaminoglycans. The chondroitin sulfates were digested with protease-free chondroitinase ABC in $40 \mathrm{~mm}$ Tris, $\mathrm{pH} 8.0,40 \mathrm{~mm}$ sodium acetate, $0.1 \mathrm{mg} / \mathrm{ml} \mathrm{BSA}$. Typically, $2.5 \mu \mathrm{g}$ of either CS4 or CS6 was incubated with 0.02 unit of chondroitinase $\mathrm{ABC}$ at $37^{\circ} \mathrm{C}$ for $1 \mathrm{hr}$. The reaction mixture was cooled on ice and $\mathrm{CaCl} 2$ was added to a final concentration of $1 \mathrm{mM}$ to inactivate the enzyme. KS was treated with keratanase $(0.1 \mathrm{unit} / \mu \mathrm{g}$ KS) in PBS (pH 7.4) containing $0.1 \mathrm{mg} / \mathrm{ml}$ BSA and protease inhibitors (2 mM PMSF and $0.1 \mathrm{mg} / \mathrm{ml}$ leupeptin) at $37^{\circ} \mathrm{C}$ for $1 \mathrm{hr}$. In control experiments, GAGs were treated with inappropriate GAG lyases. For example, CS4 was treated with keratanase and $\mathrm{KS}$ was treated with chondroitinase $\mathrm{ABC}$. The reaction mixtures were mixed with either laminin or L1 and adsorbed to PLL-coated tissue culture wells as described above.

Primary cell cultures. Cerebellar granule neurons were purified from trypsin dissociates of postnatal day 5 or 6 rat cerebella on discontinuous Percoll gradients as described previously (Hatlen, 1985). Neurons were seeded onto 48 -well plates at 20,000 cells/well $\left(250\right.$ cells $\left./ \mathrm{mm}^{2}\right)$ in Dulbecco's modified Eagle's essential medium (DMEM) containing 10\% fetal bovine serum (FBS), $25 \mathrm{~mm} \mathrm{KCl}$, and $20 \mathrm{ng} / \mathrm{ml} \mathrm{bFGF} \mathrm{After} 24$ $\mathrm{hr}$, the cultures were washed in PBS and fixed in PBS containing 2\% glutaraldehyde.

Dorsal root ganglia were isolated from embryonic day $15-16$ rats and digested with $0.25 \%$ trypsin, $0.05 \%$ collagenase for $20 \mathrm{~min}$ at $37^{\circ} \mathrm{C}$. Following neutralization and washing with serum containing medium, the ganglia were mechanically dissociated with flame-narrowed Pasteur pipettes. The cells were washed and preplated onto petri dishes in serum containing medium for $2 \mathrm{hr}$ at $37^{\circ} \mathrm{C}$ to remove fibroblasts and other non-neuronal cells. The DRG neurons were seeded at 3000 cells/well in DMEM containing 10\% FBS and $60 \mathrm{ng} / \mathrm{ml} \mathrm{NGF}$ (NGF was a gift from Dr. S. Halegoua). After $24 \mathrm{hr}$, the cultures were washed in PBS and fixed in $2 \%$ glutaraldehyde in PBS.

Quantitization of neurite length and cell attachment. The quantitation and analysis of cell attachment and neurite length was carried out as described previously (Dou and Levine, 1994). Each experiment com- 

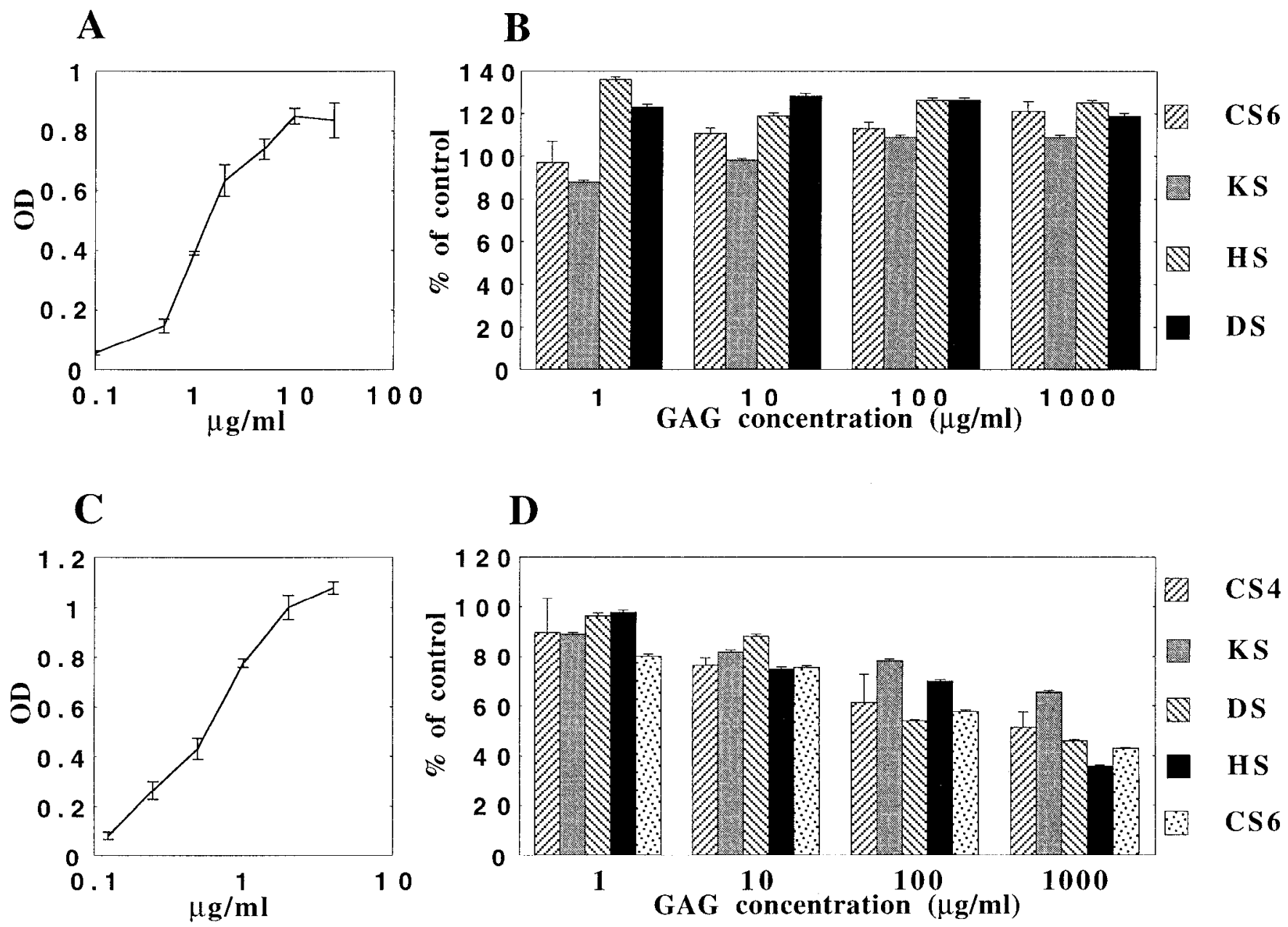

Figure 1. ELISA assays of substrate-bound laminin and L1. A, 96-well plates were coated with PLL followed by laminin at $0.1,0.5,1,2,5,10$, $25 \mu \mathrm{g} / \mathrm{ml}$. After treatment with a monoclonal antibody directed against the laminin B1 chain and an alkaline phosphatase conjugated goat antimouse antibody, the wells were reacted with Sigma alkaline phosphatase substrate and optical density $(O D)$ at $405 \mathrm{~nm}$ determined as detailed under Materials and Methods. The mean OD value and SD were determined from tetraplicate wells. Optical density is a function of the amount of laminin used to coat the wells. $B$, 96-well plates were coated with laminin at $2 \mu \mathrm{g} / \mathrm{ml}$ or mixtures of laminin and the indicated GAGs at the indicated concentrations. OD was determined as in $A$ and the percent of control OD (i.e., OD measurements from wells coated with laminin alone) is plotted versus the concentration of the GAGs used. $C, 96$-well plates were coated with PLL followed by L1 at $0.125,0.25,0.5,1,2$, and $4 \mu \mathrm{g} / \mathrm{ml}$ and OD determined as described above using monoclonal antibody $74-5 \mathrm{H} 7$ as a probe for substrate-bound Ll (Lemmon, et al., 1989). As was the case with laminin-coated wells, OD is a function of the amount of L1 added to the wells. $D, 96$-well plates were coated with mixtures of L1 and the indicated GAGs and optical densities determined as described above. The percent of control OD is plotted versus the concentrations of the GAG used.

prised duplicate wells and most experiments were repeated 3-10 times. A neurite was defined as a process extending from neuronal cell body by more than one cell diameter. A minimum of 50 neurites from duplicate wells of each substrate condition were measured for every experiment, except for a few strongly inhibitory substrates on which very few cells grew out neurites. In those cases, we scored all the neurites we could find. For cells that had more than one neurite, only the longest neurite was measured. Only those neurites that did not contact other neurites or cell bodies were measured. The mean neurite length for each individual experiment was calculated and the means were pooled to create the summary data shown in the tables. The percentage of inhibition of neurite growth is defined as $\left[1-\left(\right.\right.$ mean $^{\text {expr }} /$ mean $\left.\left.^{\text {control }}\right)\right] \times 100$ where mean ${ }^{\mathrm{xpt}}$ is the mean length under the experimental conditions and mean ${ }^{\text {control }}$ is the mean of the appropriate controls.

\section{Results}

\section{Substrate characterization}

To assay the effects of different GAGs on neurite growth on substrates comprising laminin and the L1 glycoprotein, it was necessary to first characterize the molecular nature of the substrates being tested. As described under Materials and Methods, we used ELISA assays to determine the amount of laminin and $L 1$ bound to surfaces in the presence of the various GAGs and to determine the amount of CS4 and CS6 bound to the lamininand L1-coated surfaces. In the case of laminin, we used a monoclonal antibody directed against the Bl chain. As shown in Figure $1 A$, optical density is a direct measure of the input amount of laminin over a concentration range of $0.5-10 \mu \mathrm{g} / \mathrm{ml}$. When PLL-coated surfaces were treated with solutions containing 2 $\mu \mathrm{g} / \mathrm{ml}$ of laminin plus either CS6, KS, DS, or HS at concentrations ranging from $1-1000 \mu \mathrm{g} / \mathrm{ml}$, there was no reduction in the amount of laminin bound to the substrate as compared to surfaces coated with laminin alone (Fig. $1 B$ ). A similar assay using monoclonal antibody 74-5H7 (Lemmon et al., 1989) was performed to measure substrate bound L1. As was the case with the assays designed to detect laminin, optical density is a function of the input amount of L1 (Fig. 1C). Mixing CS4, CS6, DS, KS, or HS with $\mathrm{LI}$ resulted in a concentration-dependent reduction in the amount of $\mathrm{L} 1$ bound to the substrate (Fig. 1D). 
A

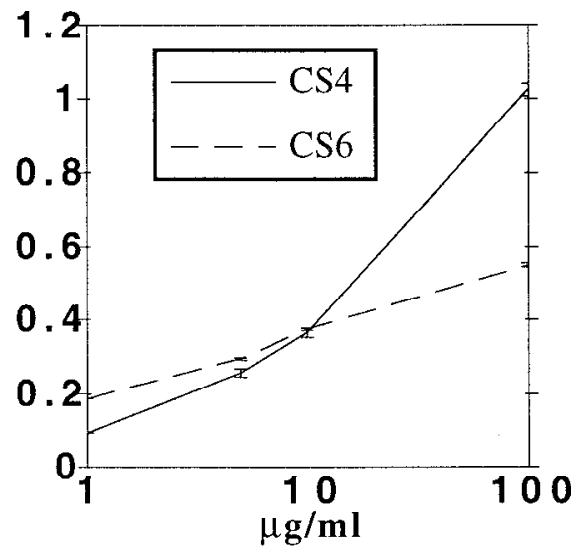

B

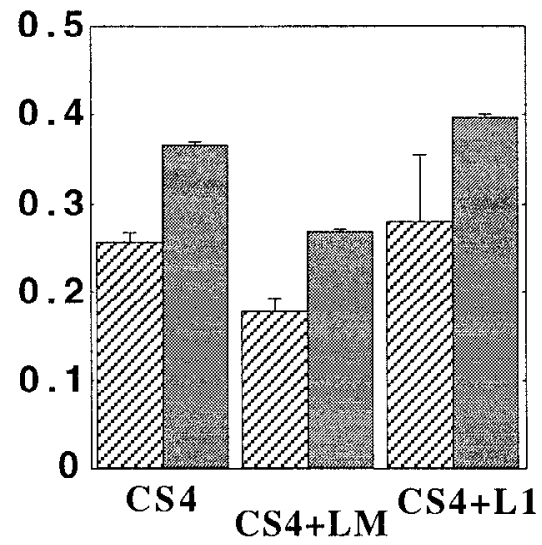

C

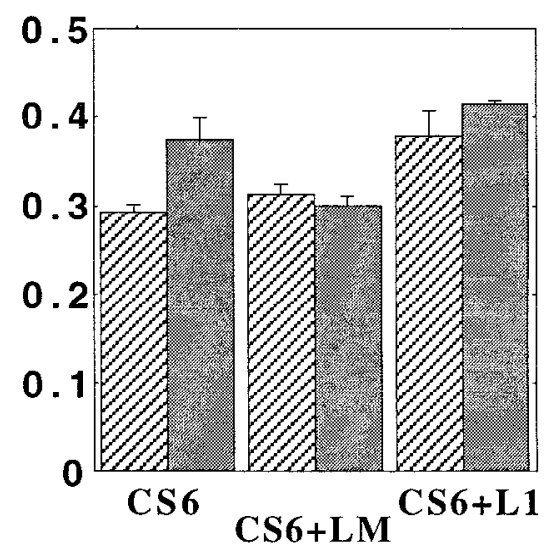

Figure 2. ELISA assay of substrate-bound chondroitin sulfates. A, 96-well plates were coated with PLL followed by either CS4 or CS6 at 1-100 $\mu \mathrm{g} / \mathrm{ml}$ as detailed under Materials and Methods. The optical density (OD) values from duplicate wells are plotted versus the concentration of GAGs used to coat the substrate. The OD values increase as the concentration of the GAGs increases. The anti-CS antibody (CS-56) is more reactive against CS6 than CS4 (Avnur and Geiger, 1984); hence it was used at 1:500 (4 $\mu \mathrm{g} / \mathrm{ml})$ to detect CS4 and 1:5000 (400 ng/ml) to detect CS6. B, Optical density values for wells coated with CS4 alone or CS4 mixed with laminin (LM) or the L1 glycoprotein. The presence of laminin reduces the amount of CS4 bound to the substrates by 25-30\%. The L1 glycoprotein does not alter the amount of GAGs bound to the substrates. C, Optical density values for CS6 alone and for CS6 mixed with either LM or L1. The cell adhesion proteins do not reduce the amount of CS6 bound to the substrates. In $B$ and $C$, the hatched bars represent experiments in which the GAGs were used at $5 \mu \mathrm{g} / \mathrm{ml}$ and the solid bars represent experiments in which the GAGs were used at $10 \mu \mathrm{g} / \mathrm{ml}$. The data shown are the means and SDs.

When each of the GAGs was used at $1 \mu \mathrm{g} / \mathrm{ml}$, only CS6 caused a significant reduction in the amount of L1 bound to the substrate. As the concentration of CS6, HS, and DS was increased from $10-1000 \mu \mathrm{g} / \mathrm{ml}$, the reduction in $\mathrm{L} 1$ binding to the surfaces also increased reaching a maximum reduction of $50-60 \%$ relative to control substrates. Mixing L1 with CS4 at $1 \mathrm{mg} / \mathrm{ml}$, however, lead to only a $20 \%$ reduction in substrate bound L1. Thus, while GAGs, over a 1000-fold concentration range, do not reduce laminin binding to the substrate, they can reduce the amount of substrate bound L1.

We employed an ELISA assay to determine (1) whether exogenous CS GAGs bind to the tissue culture surfaces used and (2) whether laminin or $L 1$ reduce the amount of CS GAG bound to the substrate. Figure $2 A$ shows that the optical density values increase as the concentration of CS GAGs increases indicating that there are more molecules bound when higher concentrations of GAGs are used to coat the culture substrates. As shown in Figure $2 C$, when CS6 was mixed with either laminin or the L1 glycoprotein, the amount of the GAG bound to the surfaces did not differ significantly from the amount that was bound in the absence of the cell adhesion proteins. Thus, the presence of cell adhesion proteins does not interfere with the binding of CS6 to PLL-coated tissue culture surfaces. In the case of CS4, however, the amount of the GAG bound to the PLL-coated surfaces in the presence of laminin was $25-30 \%$ less than the amount bound in the absence of protein (Fig. $2 B$ ). The $\mathrm{L} 1$ glycoprotein did not reduce the amount of CS4 bound (Fig. $2 B$ ). Although laminin causes a reduction in the amount of $\mathrm{CS} 4$ bound to the tissue culture surfaces, as shown below, these reduced amounts of GAG were capable of neutralizing the neurite promoting properties of laminin.

\section{GAGs inhibit neurite growth from CNS neurons on laminin- but not on L1-coated surfaces}

To determine whether substrate bound GAGs modulate neurite outgrowth from CNS neurons, we plated postnatal day 5 cerebellar granule neurons on surfaces coated with either laminin or the $\mathrm{L} 1$ glycoprotein (both at $2 \mu \mathrm{g} / \mathrm{ml}$ ) or with these same molecules mixed with different GAGs. Our previous studies have shown that when both laminin and $\mathrm{L} 1$ are used at a concentration of $2 \mu \mathrm{g} / \mathrm{ml}$, neurite outgrowth from cerebellar granule neurons is $90 \%$ of the maximum lengths achieved at higher concentrations of the cell adhesion molecules (Dou and Levine, 1994). When used at this concentration, between $65-80 \%$ of the input molecules bound to the PLL-coated tissue culture surfaces (Dou and Levine, 1994).

As shown in Figure $3 A-D$, cerebellar granule neurons attached equally well to the laminin-coated surfaces and the surfaces coated with laminin mixed with the different GAGs. This demonstrates that the GAGs do not inhibit cell attachment in this assay. Among the five GAGs tested, CS4, CS6 and KS were potent inhibitors of axonal extension and initiation. As shown in Table 1, maximum growth inhibition occurred when CS6 and $\mathrm{KS}$ were used at $10 \mu \mathrm{g} / \mathrm{ml}$. In the case of CS4, $10 \mu \mathrm{g} / \mathrm{ml}$ gave approximately $75 \%$ of the maximum inhibitory effect. As shown in Figure $4 A$, on laminin alone, $50 \%$ of all neurites measured

Figure 3. GAGs inhibit neurite outgrowth from cerebellar neurons on laminin but not on L1-coated surfaces. Cerebellar granule neurons were isolated from postnatal day 5 rats and grown on different substrates for $24 \mathrm{hr}$ as described in Materials and Methods. The substrates are: $A$, laminin $(2 \mu \mathrm{g} / \mathrm{ml}) ; B$, laminin plus CS4 $(10 \mu \mathrm{g} / \mathrm{ml}) ; C$, laminin plus $\mathrm{KS}(10 \mu \mathrm{g} / \mathrm{ml}) ; D$, laminin plus HS $(10 \mu \mathrm{g} / \mathrm{ml}) ; E, \mathrm{~L} 1(2 \mu \mathrm{g} / \mathrm{ml}) ; F, \mathrm{~L} 1 \mathrm{plus} \mathrm{CS} 6$ $(100 \mu \mathrm{g} / \mathrm{ml}) ; G, \mathrm{Ll}$ plus $\mathrm{KS}(100 \mu \mathrm{g} / \mathrm{ml}) ; H, \mathrm{Ll}$ plus HS $(10 \mu \mathrm{g} / \mathrm{ml})$. Note that fewer cells extended neurites and the neurites were shorter on laminin plus CS or KS relative to on laminin alone. Neurite extension on L1 and CS or KS was indistinguishable from that on L1 control, however, both the number of cells growing neurites and the neurite length were reduced on L1 plus HS. Scale bar, $50 \mu \mathrm{m}$. 

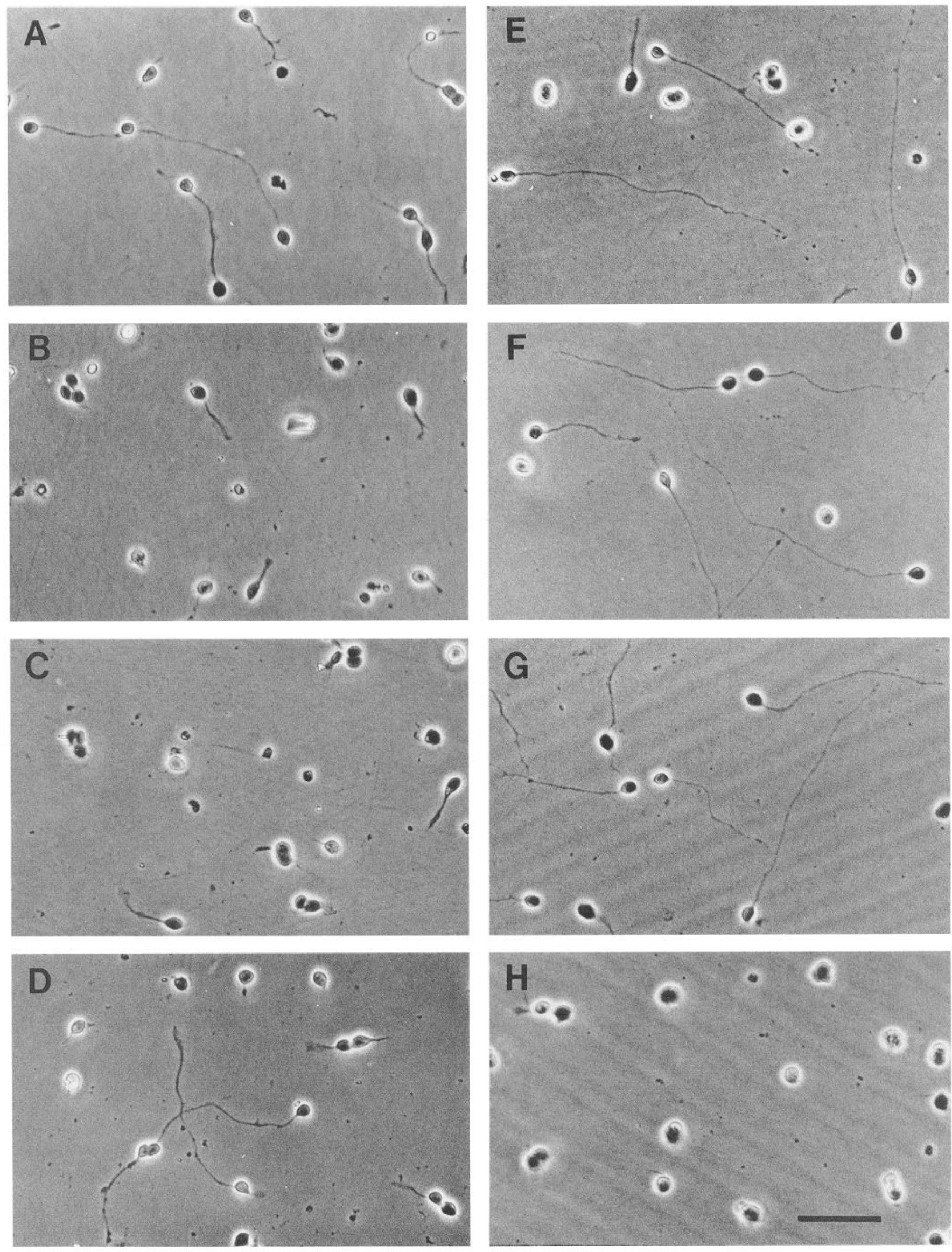
Table 1. Effect of GAGs on neurite growth from cerebellar granule neurons on laminin-coated substrates

\begin{tabular}{|c|c|c|c|}
\hline Substrate & $\begin{array}{l}\% \text { Cells } \\
\text { with neurites }\end{array}$ & $\begin{array}{l}\text { Mean neurite } \\
\text { length, } \mu \mathrm{m}(n)\end{array}$ & $\%$ Inhibition \\
\hline Lamininin $(2 \mu \mathrm{g} / \mathrm{nl})$ & $60 \pm 10$ & $84 \pm 12(783)$ & \\
\hline Laminin + CS4 $(1 \mu \mathrm{g} / \mathrm{ml})$ & $56 \pm 10$ & $77 \pm 28(69)$ & 8 \\
\hline Laminin + CS4 $(10 \mu \mathrm{g} / \mathrm{ml})$ & $33 \pm 11^{*}$ & $58 \pm 7(270)^{* *}$ & 31 \\
\hline \multicolumn{4}{|l|}{ Laminin + CS4 $(10 \mu \mathrm{g} / \mathrm{ml}$, } \\
\hline C'ase digested) & $48 \pm 12$ & $77 \pm 2(162)$ & 8 \\
\hline Laminin + CS4 $(100 \mu \mathrm{g} / \mathrm{ml})$ & $18 \pm 7^{*}$ & $49 \pm 5(145)^{*}$ & 42 \\
\hline Laminin + CS4 $(1 \mathrm{mg} / \mathrm{ml})$ & $13 \pm 5^{*}$ & $48 \pm 11(86)^{*}$ & 43 \\
\hline Laminin + CS6 $(1 \mu \mathrm{g} / \mathrm{ml})$ & $48 \pm 11$ & $74 \pm 30(70)$ & 12 \\
\hline Laminin + CS6 $(10 \mu \mathrm{g} / \mathrm{ml})$ & $25 \pm 5^{*}$ & $50 \pm 2(101)^{*}$ & 40 \\
\hline Laminin + CS6 $(100 \mu \mathrm{g} / \mathrm{ml})$ & $24 \pm 7^{*}$ & $50 \pm 1(125)^{*}$ & 40 \\
\hline Laminin + CS6 $(1 \mathrm{mg} / \mathrm{ml})$ & $31 \pm 9 *$ & $49 \pm 2(93)^{*}$ & 42 \\
\hline Laminin $+\mathrm{KS}(1 \mu \mathrm{g} / \mathrm{ml})$ & $48 \pm 10$ & $75 \pm 10(101)$ & 11 \\
\hline Laminin $+\mathrm{KS}(10 \mu \mathrm{g} / \mathrm{ml})$ & $25 \pm 6^{*}$ & $49 \pm 4(244)^{*}$ & 42 \\
\hline \multicolumn{4}{|l|}{ Laminin $+\mathrm{KS}(10 \mu \mathrm{g} / \mathrm{ml}$, } \\
\hline $\mathrm{K}^{\prime}$ ase digested) & $54 \pm 6$ & $82 \pm 3(122)$ & 2 \\
\hline Laminin $+\mathrm{KS}(100 \mu \mathrm{g} / \mathrm{ml})$ & $24 \pm 5^{*}$ & $48 \pm 3(230)^{*}$ & 43 \\
\hline Laminin + KS $(1 \mathrm{mg} / \mathrm{ml})$ & $33 \pm 7^{*}$ & $50 \pm 2(88)^{*}$ & 40 \\
\hline Laminin + HS $(1 \mu \mathrm{g} / \mathrm{ml})$ & $54 \pm 8$ & $81 \pm 21(74)$ & 4 \\
\hline Laminin $+\mathrm{HS}(10 \mu \mathrm{g} / \mathrm{ml})$ & $39 \pm 10^{* *}$ & $72 \pm 4$ (137) & 14 \\
\hline Laminin + HS $(100 \mu \mathrm{g} / \mathrm{ml})$ & $34 \pm 7^{*}$ & $72 \pm 5(130)$ & 14 \\
\hline Laminin + HS $(1 \mathrm{~g} / \mathrm{ml})$ & $44 \pm 14$ & $63 \pm 17(56)^{* * *}$ & 25 \\
\hline Laminin $+\mathrm{DS}(1 \mu \mathrm{g} / \mathrm{ml})$ & $60 \pm 9$ & $84 \pm 33(70)$ & 0 \\
\hline Laminin + DS $(10 \mu \mathrm{g} / \mathrm{ml})$ & $64 \pm 7$ & $75 \pm 8 \quad(191)$ & 11 \\
\hline Laminin + DS $(100 \mu \mathrm{g} / \mathrm{ml})$ & $45 \pm 8$ & $57 \pm 3(235)^{* *}$ & 32 \\
\hline Laminin + DS $(1 \mathrm{mg} / \mathrm{ml})$ & $20 \pm 3^{*}$ & $38 \pm 12(23)^{*}$ & 55 \\
\hline
\end{tabular}

Cerebellar granule neurons were seeded onto the indicated substrates. After $24 \mathrm{hr}$, the percentages of cells with neurites and neurite lengths were determined as described in Materials and Methods. Data shown are the percentage of attached cells with neurites (mean \pm SD) and the mean neurite length ( \pm SD) from 1-12 separate experiments. The numbers in parentheses $(n)$ are the total numbers of neurites measured for each substrate condition. There was no difference in the total number of attached cells per unit area under all conditions tested. C'ase, Chondroitinase $\mathrm{ABC} ; \mathrm{K}$ 'ase, keratanase.

${ }^{*}, p<0.001 ; * *, 0.001<p<0.01$ (Student's $t$ test); where not indicated, the numbers are not statistically different $(p>0.15)$ from the control values on laminin alone.

were greater than $85 \mu \mathrm{m}$. On mixtures of laminin and CS4, $50 \%$ of all neurites were greater than $55 \mu \mathrm{m}$, on $\mathrm{KS}$ and laminin, $50 \%$ were greater than $48 \mu \mathrm{m}$ and on CS6 and laminin, the median length was $35 \mu \mathrm{m}$. The percentage of the attached cells that extended neurites was also reduced from a value of about $60 \%$ on laminin alone to between $25-33 \%$ on the GAG-containing surfaces (Table 1). Dermatan sulfate, which differs from CS4 and CS6 in that it contains $\alpha$-L-iduronic acid rather than $\beta$-D-glucoronic acid residues, was much less effective as an inhibitor of axonal growth (Table 1). Although high levels of inhibition could be achieved with DS, this inhibition required 10100-fold higher concentrations of DS than of CS4, CS6, or KS. Heparan sulfate was also a weak inhibitor of axonal growth from cerebellar neurons on laminin-coated surfaces and statistically significant inhibition was achieved only when HS was used at a concentration of $1 \mathrm{mg} / \mathrm{ml}$ (Table 1). These growth inhibitory effects were due to the GAGs themselves and not any contaminating material in the commercially available preparations used since digestion with the appropriate GAG lyases destroyed the growth inhibitory activity (Table 1). Moreover, digestion with inappropriate GAG lyases, that is, digcstion of CS4 with keratanase or digestion of $\mathrm{KS}$ with chondroitinase $\mathrm{ABC}$, had no ef- fect on the ability of the GAGs to modify neurite growth. For example, the mean neurite length on laminin and $\mathrm{KS}(10 \mu \mathrm{g} /$ $\mathrm{ml}$ ) that had been treated with chondroitinase $\mathrm{ABC}$ was $43 \mu \mathrm{m}$ and the mean length on laminin and CS4 $(10 \mu \mathrm{g} / \mathrm{ml})$ that had been treated with keratanase was $58 \mu \mathrm{m}$, values that are comparable to the mean neurite lengths on laminin and the respective GAGs without any enzyme treatment. As shown in Figure $3 A-$ $D$, there were no obvious morphological differences among the cells grown on these various substrates except that the neurites were shorter on laminin plus CS or KS. Thus, with the exception of HS, all GAGs tested were able to inhibit the potent growthpromoting effects of laminin.

Cerebellar granule neurons extend their axons in vivo within areas rich in the L1 glycoprotein (Faissner et al., 1984; Stallcup et al., 1985). To determine whether GAGs can inhibit neurite growth in an assay that may better approximate physiological conditions, we evaluated the abilities of GAGs to influence neurite growth on L1-coated surfaces.

As shown in Table 2, CS4, CS6, and KS at concentrations of up to $100 \mu \mathrm{g} / \mathrm{ml}$ did not inhibit neurite growth from cerebellar neurons on L1-coated surfaces. Both the percentages of attached cells that extended neurites and the mean neurite lengths on 
A

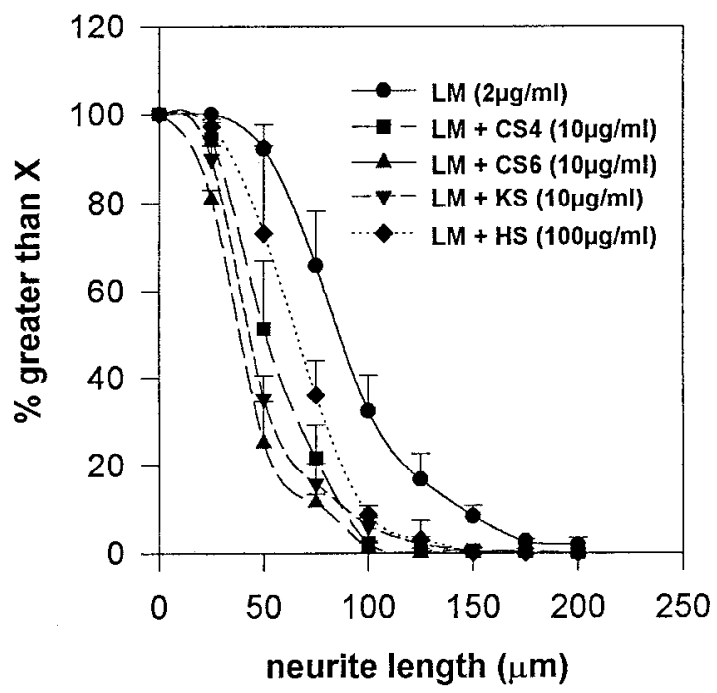

B

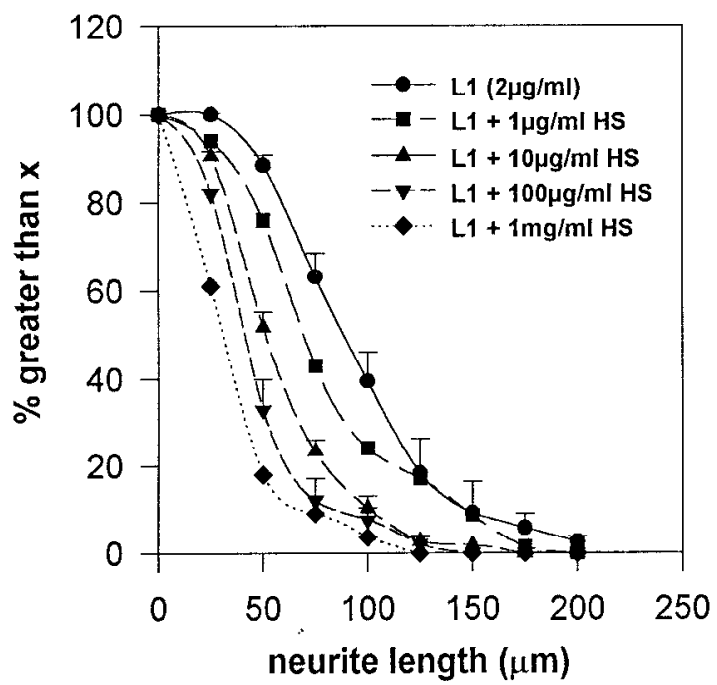

Figure 4. Quantitative analysis of neurite growth from cerebellar neurons on different substrates. $A$, Cumulative neurite length histograms showing the distribution of neurites according to length on laminin alone, laminin plus CS4, laminin plus CS6, laminin plus KS, and laminin plus HS. Data were pooled from 12 separate experiments and distribution was plotted as percentage of neurons with neurites (y-axis) longer than a given length ( $x$-axis). These GAGs caused a shift of neurite distribution curve towards the left (median neurite length reduced). $B$, Distribution of neurite lengths on L1 alone, L1 plus 1, 10, 100, 1000 $\mu \mathrm{g} / \mathrm{ml}$ of HS. HS inhibits the growth of cerebellar neurons on the L1coated surfaces in a dose-dependent manner.

surfaces coated with LI and each of these three GAGs were statistically identical to those on surfaces coated with L1 alone (Table 2, Fig. 3E-G). No inhibition by KS at concentrations up to $1 \mathrm{mg} / \mathrm{ml}$ was observed and statistically significant inhibition by the chondroitin sulfates was seen only when they were used at $1 \mathrm{mg} / \mathrm{ml}$ (Table 2). In contrast to the lack of significant effects of KS and the chondroitin sulfates, HS was a potent inhibitor of neurite extension on L1-coated surfaces (Table 2). As shown in Figure $4 B$, HS, at $1 \mu \mathrm{g} / \mathrm{ml}$, reduced the median neurite length from $96 \mu \mathrm{m}$ to $75 \mu \mathrm{m}$. The median length was further reduced as the concentration of $\mathrm{HS}$ was increased reaching a maximum of $62 \%$ inhibition of growth when $\mathrm{HS}$ was used at $1 \mathrm{mg} / \mathrm{ml}$. Dermatan sulfate, at concentrations grcatcr than $50 \mu \mathrm{g} / \mathrm{ml}$, also inhibited both the initiation and the extension. of neurites (Table
Table 2. Effects of GAGs on the growth of cerebellar neurons on L1-coated substrates

\begin{tabular}{|c|c|c|c|}
\hline Substrate & $\begin{array}{l}\% \text { Cells } \\
\text { with } \\
\text { neurites }\end{array}$ & $\begin{array}{l}\text { Neurite } \\
\text { length, } \\
\mu \mathrm{m}(n)\end{array}$ & $\begin{array}{l}\% \\
\text { Inhi- } \\
\text { bition }\end{array}$ \\
\hline $\mathrm{Ll}(2 \mu \mathrm{g} / \mathrm{ml})$ & $55 \pm 12$ & $96 \pm 7(608)$ & \\
\hline $\mathrm{L} 1+\operatorname{CS} 4(1 \mu \mathrm{g} / \mathrm{ml})$ & $63 \pm 6$ & $95 \pm 27(117)$ & 1 \\
\hline $\mathrm{L} 1+\mathrm{CS} 4(10 \mu \mathrm{g} / \mathrm{ml})$ & $62 \pm 11$ & $94 \pm 9(132)$ & 2 \\
\hline $\mathrm{Ll}+\mathrm{CS} 4(100 \mu \mathrm{g} / \mathrm{ml})$ & $62 \pm 14$ & $97 \pm 11(159)$ & \\
\hline $\mathrm{L} 1+\mathrm{CS} 4(1 \mathrm{mg} / \mathrm{ml})$ & $17 \pm 4^{*}$ & $47 \pm 4(70)^{*}$ & 51 \\
\hline $\mathrm{L} 1+\operatorname{CS} 6(1 \mu \mathrm{g} / \mathrm{ml})$ & $55 \pm 10$ & $91 \pm 33(52)$ & 5 \\
\hline $\mathrm{L} 1+\operatorname{CS} 6(10 \mu \mathrm{g} / \mathrm{ml})$ & $65 \pm 10$ & $103 \pm 2(154)$ & \\
\hline $\mathrm{L} 1+\mathrm{CS} 6(100 \mu \mathrm{g} / \mathrm{ml})$ & $64 \pm 4$ & $95 \pm 10(138)$ & 1 \\
\hline $\mathrm{L} 1+\mathrm{CS} 6(1 \mathrm{mg} / \mathrm{ml})$ & $27 \pm 4^{*}$ & $50 \pm 4(87)^{*}$ & 48 \\
\hline $\mathrm{L} 1+\mathrm{KS}(10 \mu \mathrm{g} / \mathrm{ml})$ & $51 \pm 14$ & $95 \pm 4$ (243) & 1 \\
\hline $\mathrm{L} 1+\mathrm{KS}(100 \mu \mathrm{g} / \mathrm{ml})$ & $59 \pm 12$ & $95 \pm 5$ (393) & 1 \\
\hline $\mathrm{L} 1+\mathrm{KS}(1 \mathrm{mg} / \mathrm{ml})$ & $55 \pm 5$ & $87 \pm 20(97)$ & 9 \\
\hline $\mathrm{L} 1+\mathrm{HS}(1 \mu \mathrm{g} / \mathrm{ml})$ & $53 \pm 10$ & $78 \pm 5(135)$ & 19 \\
\hline $\mathrm{L} 1+\mathrm{HS}(10 \mu \mathrm{g} / \mathrm{ml})$ & $28 \pm 8^{*}$ & $58 \pm 1(254)^{*}$ & 40 \\
\hline $\mathrm{Ll}+\mathrm{HS}(100 \mu \mathrm{g} / \mathrm{ml})$ & $21 \pm 5^{*}$ & $46 \pm 8(205)^{*}$ & 52 \\
\hline $\mathrm{L} 1+\mathrm{HS}(1 \mathrm{mg} / \mathrm{ml})$ & $30 \pm 5^{*}$ & $36 \pm 7(56)^{*}$ & 62 \\
\hline $\mathrm{L} 1+\mathrm{DS}(1 \mu \mathrm{g} / \mathrm{ml})$ & $60 \pm 16$ & $95 \pm 37(54)$ & 1 \\
\hline $\mathrm{L} 1+\mathrm{DS}(10 \mu \mathrm{g} / \mathrm{ml})$ & $55 \pm 13$ & $105 \pm 4$ & \\
\hline $\mathrm{L} 1+\mathrm{DS}(50 \mu \mathrm{g} / \mathrm{ml})$ & $39 \pm 2 * *$ & $67 \pm 22(48)^{* * *}$ & 30 \\
\hline $\mathbf{L} 1+\mathrm{DS}(100 \mu \mathrm{g} / \mathrm{ml})$ & $24 \pm 6^{*}$ & $61 \pm 5(125)^{*}$ & 36 \\
\hline $\mathrm{L} 1+\mathrm{DS}(1 \mathrm{mg} / \mathrm{ml})$ & $16 \pm 14^{*}$ & $42 \pm 11(28)^{*}$ & 56 \\
\hline
\end{tabular}

Cerebellar granule neurons were seeded onto the indicated substrates. After 24 $\mathrm{hr}$, the percentages of cells with neurites and neurite lengths were determined as described in Materials and Methods. Data shown are the percentage of attached cells with neurites (mean \pm SD) and the mean neurite length $( \pm$ SD) from one to nine separate experiments for each condition. $n$ indicates the total number of neurites measured for each substrate condition. There was no difference in the total number of attached cells per unit area under all conditions tested.

$*, p<0.001 ; * *, 0.001<p<0.01$ (Student's $t$ test); where not indicated, the numbers are not statistically different $(p>0.2)$ from the control values on laminin alone.

2). Thus, while HS and DS inhibit the growth of cerebellar neurons on L1-coated surfaces, other GAGs (CS4, CS6, and KS) do not inhibit neurite elongation on the Ll substrates when used at concentrations sufficient to cause robust inhibition on laminin substrates.

Effects of GAGs on the growth of embryonic rat DRG neurons

The studies described above demonstrate that CS and KS GAGs inhibit the growth of a population of rat CNS neurons on laminin-coated surfaces but not on L1-coated surfaces and that HS and DS inhibit neurite growth from these neurons on L1-but not on laminin-coated substrates. To determine whether this growth inhibition is specific to CNS neurons or is a general property of all neurons, we tested the effects of these GAGs on axonal growth from rat DRG neurons. As DRG neurons extend their axons in an environment containing both abundant laminin (Sanes, 1989) and the L1 glycoprotein (Stallcup et al., 1985), we evaluated the growth modulatory effects of the panel of GAGs on substrates containing either laminin or the L1 glycoprotein.

When DRG neurons were plated onto surfaces that had been coated with PLL followed by laminin, $65 \%$ of the attached cells elaborated long (mean length $=191 \mu \mathrm{m}$ ) neurites after $24 \mathrm{hr}$ 
Table 3. Effects of GAGs on the growth of DRG neurons on laminin-coated substrates

\begin{tabular}{|c|c|c|c|}
\hline Substrate & $\begin{array}{l}\% \text { Cells } \\
\text { with neurites }\end{array}$ & $\begin{array}{l}\text { Neuritc } \\
\text { length, } \mu \mathrm{m}(n)\end{array}$ & $\%$ Inhibition \\
\hline Laminin $(2 \mu \mathrm{g} / \mathrm{ml})$ & $65 \pm 9$ & $191 \pm 36(320)$ & \\
\hline Laminin + CS4 $(1 \mu \mathrm{g} / \mathrm{ml})$ & $59 \pm 4$ & $180 \pm 45(55)$ & 6 \\
\hline Laminin + CS4 $(10 \mu \mathrm{g} / \mathrm{ml})$ & $12 \pm 11 *$ & $76 \pm 10(83)^{*}$ & 60 \\
\hline Laminin + CS4 $(100 \mu \mathrm{g} / \mathrm{ml})$ & $38 \pm 9^{*}$ & $83 \pm 12(88)^{*}$ & 57 \\
\hline Laminin + CS6 $(1 \mu \mathrm{g} / \mathrm{ml})$ & $65 \pm 10$ & $170 \pm 55(50)$ & 11 \\
\hline Laminin + CS6 $(10 \mu \mathrm{g} / \mathrm{ml})$ & $39 \pm 11 *$ & $85 \pm 10(92)^{*}$ & 55 \\
\hline Laminin + CS6 $(100 \mu \mathrm{g} / \mathrm{ml})$ & $41 \pm 8^{*}$ & $73 \pm 4(60)^{*}$ & 62 \\
\hline Laminin $+\mathrm{KS}(1 \mu \mathrm{g} / \mathrm{ml})$ & $68 \pm 4$ & $145 \pm 49(56)$ & 24 \\
\hline Laminin $+\mathrm{KS}(10 \mu \mathrm{g} / \mathrm{ml})$ & $35 \pm 7^{*}$ & $62+13(85)^{*}$ & 68 \\
\hline Laminin $+\mathrm{KS}(100 \mu \mathrm{g} / \mathrm{ml})$ & $35 \pm 12^{*}$ & $63 \pm 3(44)^{*}$ & 67 \\
\hline $\mathrm{I}$ aminin $+\mathrm{HS}(10 \mu \mathrm{g} / \mathrm{ml})$ & $58 \pm 18$ & $181 \pm 49(171)$ & 5 \\
\hline Laminin + HS $(100 \mu \mathrm{g} / \mathrm{ml})$ & $56 \pm 9$ & $166 \pm 40(174)$ & 13 \\
\hline Laminin + HS (1 mg/ml) & $56 \pm 16$ & $149 \pm 44(48)$ & 22 \\
\hline Laminin + DS $(10 \mu \mathrm{g} / \mathrm{ml})$ & $48 \pm 14$ & $154 \pm 53(137)$ & 19 \\
\hline Laminin + DS $(100 \mu \mathrm{g} / \mathrm{ml})$ & $53 \pm 12$ & $159 \pm 45(143)$ & 17 \\
\hline Laminin + DS $(1 \mathrm{mg} / \mathrm{ml})$ & $56 \pm 9$ & $161 \pm 57(52)$ & 16 \\
\hline
\end{tabular}

Embryonic day 15 rat DRG neurons were seeded onto the indicated substrates. After 24 hr, the percentages of cells with neurites and neurite lengths were determined as described in Materials and Methods. Data shown are the means and SDs from one to five separate experiments. $n$ indicates the total number of neurites measured for each substrate condition.

*, $p<0.001$ (Student's $t$ test); where not indicated, the numbers are not statistically different $(p>0.2)$ from the control values on laminin alone.

growth (Table 3). The majority of neurons were either unipolar or bipolar in appearance and the growth cones often had long filopodia (Fig. 5A). When grown on surfaces comprising laminin and either CS4, CS6, or $\mathrm{KS}$, the DRG neurons gave rise to shorter neurites (Fig. 5B,C, Table 3). Chondroitin 4-sulfate, CS6, and $\mathrm{KS}$, at $10 \mu \mathrm{g} / \mathrm{ml}$, inhibited neurite growth by 55 to $68 \%$ relative to growth on laminin alone (Fig. 6, Table 3). Each of these three GAGs was an equally potent inhibitor of neurite growth and the growth inhibitory effects appeared to be maximal at a concentration of $10 \mu \mathrm{g} / \mathrm{ml}$ (Table 3). As shown in Figure $5 B$, growth inhibition by GAGs often resulted in growth cones with a "stunted" appearance characterized by numerous short filopodia. Ileparan sulfate and dermatan sulfate, on the other hand, did not have significant inhibitory effects on the growth of these neurons as the mean neurite lengths on HS- or DScontaining surfaces were not statistically different from that on laminin control surfaces (Table 3, Fig. 5D). These data demonstrate that the growth inhibitory activities of CS4, CS6, and $\mathrm{KS}$ on laminin-containing substrates are equivalent whether assayed on central or peripheral neurons.

When embryonic DRG neurons were grown on the L1-coated substrates, most neurons extended a single, short neurite (Fig. $5 E$ ). The morphology of growth cones on L1 substrate differed from that on laminin-coated surfaces. On L1-coated surfaces, growth cones were large and characterized by lamellipodia, whereas on laminin-coated surfaces, small growth cones with long filopodia predominated (compare Fig. $5 A, E$ ). These differences in growth cone morphology, which were not analyzed quantitatively, closely resemble those reported by Payne and collcagucs (1992) for chick DRG neurons. With the exception of DS at a concentration of $1 \mathrm{mg} / \mathrm{ml}$, none of the GAGs tested inhibited the growth of DRG neurons on the I.1-coated surfaces (Table 4). Chondroitin 4-sulfate stimulated neurite growth by $30-40 \%$ (Table 4 ). The neurons grown on surfaces containing CS4, KS, or HS were morphologically indistinguishable from those grown on L1 alone (Fig. $5 E-H$ ). Thus, in contrast to their growth inhibitory effects on laminin substrates, GAGs do not exert negative influences over DRG neurite elongation on L1containing surfaces.

\section{Discussion}

Proteoglycans and their covalently attached GAG chains have attracted much attention recently as molecules that may encode both positive and negative growth cone guidance cues (Snow et al., 1990a; Cole and McCabe, 1991; Oohira et al., 1991; Lafont et al., 1992, 1994; Grumet et al., 1993, Faissner et al., 1994). The molecular diversity of proteoglycans and GAGs, their multifunctional structure, and their ability to form stable complexes

Figure 5. GAGs inhibit neurite outgrowth from DRG neurons on laminin- but not on L1-coated surfaces. DRG neurons were isolated from embryonic day 15 rats and plated onto PLL-coated tissue culture wells containing various substrates as described in Materials and Methods. The cells were fixed after $24 \mathrm{hr}$ growth and photographed. The substrates are: $A$, laminin $(2 \mu \mathrm{g} / \mathrm{ml}) ; B$, laminin plus CS4 $(10 \mu \mathrm{g} / \mathrm{ml}) ; C$, laminin plus KS $(10 \mu \mathrm{g} / \mathrm{ml}) ; D$, laminin plus HS $(10 \mu \mathrm{g} / \mathrm{ml}) ; E, \mathrm{~L} 1(2 \mu \mathrm{g} / \mathrm{ml}) ; F, \mathrm{~L} 1$ plus CS4 $(100 \mu \mathrm{g} / \mathrm{ml}) ; G, \mathrm{~L} 1 \mathrm{plus} \mathrm{KS}(100 \mu \mathrm{g} / \mathrm{ml}) ; H$, L1 plus HS $(10$ $\mu \mathrm{g} / \mathrm{ml})$. Neurite growth on surfaces containing laminin and either CSA or KS was reduced relative to growth on laminin alone. The GAGs did not inhibit neurite growth on the L1-coated surfaces. Chondroitin 4-sulfate stimulated neurite growth from DRG neurons on L1-coated surfaces. Scale bar, $50 \mu \mathrm{m}$ 

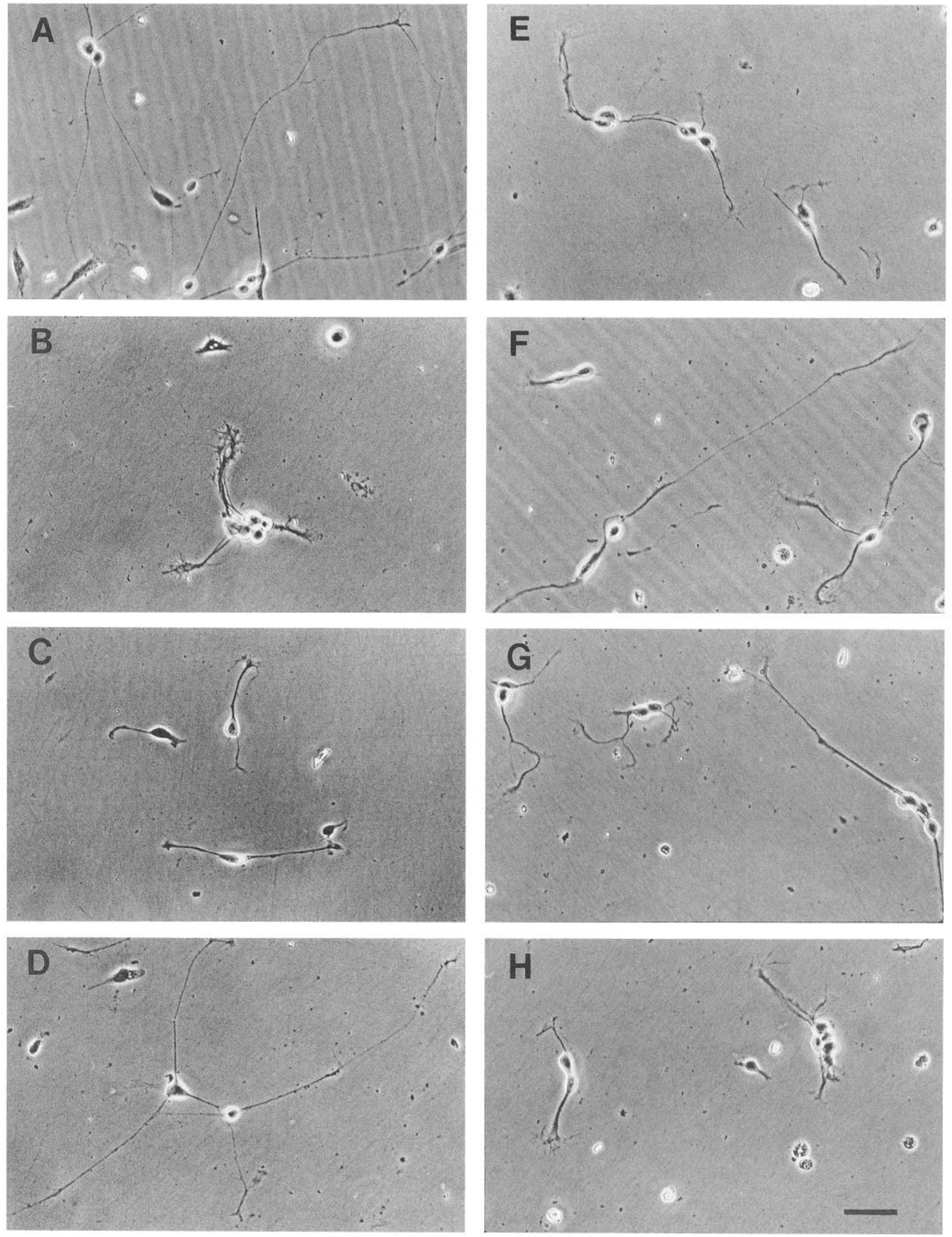


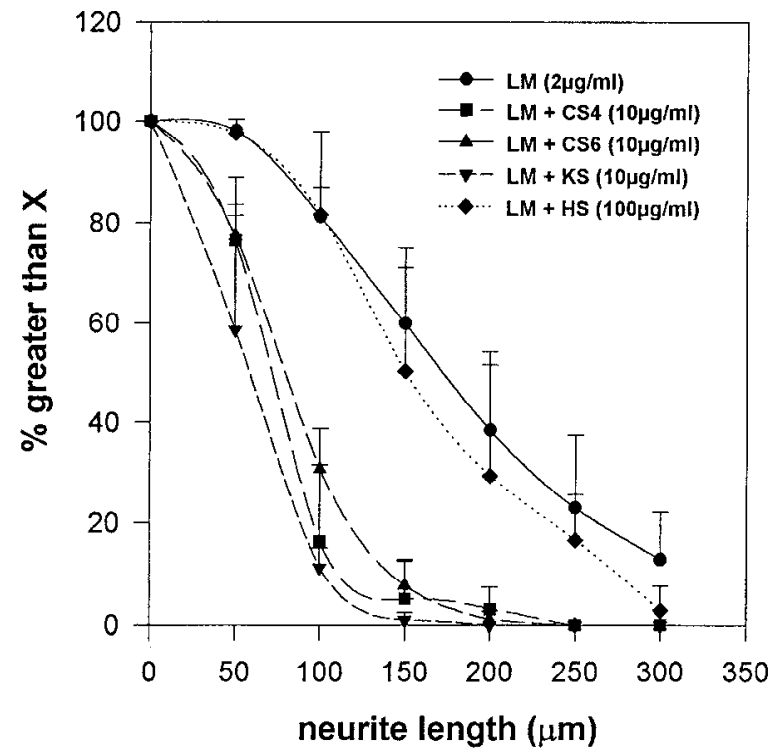

Figure 6. Quantitative analysis of neurite growth from DRG neurons on various substrates. Cumulative neurite length histograms showing the distribution of neurites according to length on laminin alone, laminin plus CS4, laminin plus CS6, laminin plus KS, and laminin plus HS. Data were pooled from five separate experiments and distribution was plotted as percentage of neurons with neurites ( $y$-axis) longer than a given length (x-axis). CS4, CS6, and $\mathrm{KS}$ all reduced significantly the median neurite length while HS at $100 \mu \mathrm{g} / \mathrm{ml}$ did not shift the neurite distribution curve.

with other ECM-associated molecules are properties of these molecules that can allow for the expression of the biological information needed to guide a growth cone to its appropriate target cell (for review, see Jackson et al., 1991; Hardingham and Fosang, 1992). Despite this high level of interest, the physiological functions of GAGs in neuronal development remain controversial and conflicting data from a number of in vitro studics have been reported (Carbonetto et al., 1983; Akeson and Warren, 1986; Verna et al., 1989; Snow et al., 1990a; McCabe and Cole, 1991; Lafont et al., 1992, 1994). We previously developed an assay to measure the effects of exogenous molecules such as proteoglycans and GAGs on the initiation and elaboration of neurites independent of their possible effects on cell substrate adhesion (Dou and Levine, 1994). Here we have used this sensitive assay to demonstrate that while most GAGs, with the exception of HS and DS, inhibit neurite growth from CNS neurons on surfaces comprising laminin, they are ineffective as growth inhibitors on substrates containing the L1 glycoprotein. In the case of DRG neurons, the effects of GAGs were more complex in that while CS4, CS6, and KS inhibited axon elongation on laminin, one of these GAGs, CS4, was able to enhance neurite
Table 4. Effects of GAGs on the growth of DRG neuron on L1coated substrates

\begin{tabular}{llll} 
Substrate & $\begin{array}{l}\text { Cells } \\
\text { with neurites }\end{array}$ & $\begin{array}{l}\text { Neurite } \\
\text { length, } \mu \mathrm{m}(n)\end{array}$ & $\begin{array}{l}\text { Inhi- } \\
\text { bition }\end{array}$ \\
\hline $\mathrm{L} 1(2 \mu \mathrm{g} / \mathrm{ml})$ & $68 \pm 12$ & $106 \pm 6(221)$ & \\
$\mathrm{L} 1+\mathrm{CS} 4(1 \mu \mathrm{g} / \mathrm{ml})$ & $63 \pm 9$ & $155 \pm 41(51)^{*}$ & \\
$\mathrm{~L} 1+\mathrm{CS} 4(10 \mu \mathrm{g} / \mathrm{ml})$ & $67 \pm 7$ & $150 \pm 9(94)^{*}$ & \\
$\mathrm{~L} 1+\mathrm{CS} 4(100 \mu \mathrm{g} / \mathrm{ml})$ & $54 \pm 14$ & $139 \pm 2(94)^{*}$ & \\
$\mathrm{~L} 1+\mathrm{CS} 4(1 \mathrm{mg} / \mathrm{ml})$ & $67 \pm 7$ & $138 \pm 31(51)^{*}$ & \\
$\mathrm{~L} 1+\mathrm{CS} 6(10 \mu \mathrm{g} / \mathrm{ml})$ & $59 \pm 18$ & $110 \pm 16(106)$ & \\
$\mathrm{L} 1+\mathrm{CS} 6(100 \mu \mathrm{g} / \mathrm{ml})$ & $48 \pm 16$ & $105 \pm 2(100)$ & 1 \\
$\mathrm{~L} 1+\mathrm{CS} 6(1 \mathrm{mg} / \mathrm{ml})$ & $47 \pm 9$ & $116 \pm 36(55)$ & \\
$\mathrm{L} 1+\mathrm{KS}(10 \mu \mathrm{g} / \mathrm{ml})$ & $57 \pm 9$ & $103 \pm 8(105)$ & 3 \\
$\mathrm{~L} 1+\mathrm{KS}(100 \mu \mathrm{g} / \mathrm{ml})$ & $51 \pm 9$ & $101 \pm 6(108)$ & 5 \\
$\mathrm{~L} 1+\mathrm{KS}(1 \mathrm{mg} / \mathrm{ml})$ & $65 \pm 9$ & $118 \pm 33(53)$ & \\
$\mathrm{L} 1+\mathrm{HS}(10 \mu \mathrm{g} / \mathrm{ml})$ & $57 \pm 9$ & $94 \pm 17(116)$ & 11 \\
$\mathrm{~L} 1+\mathrm{HS}(100 \mu \mathrm{g} / \mathrm{ml})$ & $56 \pm 14$ & $95 \pm 16(109)$ & 10 \\
$\mathrm{~L} 1+\mathrm{HS}(1 \mathrm{mg} / \mathrm{ml})$ & $55 \pm 11$ & $110 \pm 29(58)$ & \\
$\mathrm{L} 1+\mathrm{DS}(10 \mu \mathrm{g} / \mathrm{ml})$ & $68 \pm 8$ & $106 \pm 10(128)$ & 0 \\
$\mathrm{~L} 1+\mathrm{DS}(100 \mu \mathrm{g} / \mathrm{ml})$ & $65 \pm 6$ & $117 \pm 17(154)$ & \\
$\mathrm{L} 1+\mathrm{DS}(1 \mathrm{mg} / \mathrm{ml})$ & $37 \pm 11^{*}$ & $56 \pm 18(37)^{*}$ & 47 \\
\hline
\end{tabular}

Rat DRG neurons were seeded onto the indicated substrates. After 24 hr, the percentages of cells with neurites and neurite lengths were determined as described in Materials and Methods. Data shown are the means and SDs from one to four separate experiments for each condition. $n$ is the total number of neurites measured

*, $p<0.001$ (Student's $t$ test); where not indicated, the numbers are not statistically different $(p>0.2)$ from the control values on $\mathrm{L} 1$ alone.

growth on L1-coated surfaces. These data, which are summarized in Table 5, demonstrate that the effects of GAGs on neurite extension are dependent upon both the molecular context in which these carbohydrate polymers are presented to the neurons and the specific target neurons studied.

The chondroitin sulfates, in particular CS4, and hyaluronic acid (HA) are the predominant GAGs of the CNS (Margolis et al., 1975; Margolis and Margolis, 1989). Detailed studies of the composition and distribution of GAGs within the developing rat cerebellum have shown that the relative amount of CS4 GAG increases postnatally concurrent with a reduction in the amount of HA (Werz et al., 1985b). Heparan sulfate but not KS or DS has also been detected within the developing cerebellum (Werz et al., 1985a). Within the cerebellum, CS4 has been localized to the developing molecular layer where it has the potential to interact with the growth cones of elongating axons of granule neurons (Flaccus et al., 1991) as well as with the L1 glycoprotein (Faissner et al., 1984; Stallcup et al., 1985). The chondroitin

Table 5. Summary

\begin{tabular}{llllll} 
Cell type & \multicolumn{2}{l}{ Cerebellar neurons } & & DRG neurons & \\
\cline { 2 - 3 } \cline { 6 - 6 } substrate & Laminin & Ll & & Laminin & L1 \\
\hline Chondroitin 4-sulfate & Inhibitory & No effect & & Inhibitory & Stimulatory \\
Chondroitin 6-sulfate & Inhibitory & No effect & & Inhibitory & No effect \\
Keratan sulfate & Inhibitory & No effect & & Inhibitory & No effect \\
Heparan sulfate & No effect & Inhibitory & & No effect & No effect \\
Dermatan sulfate & No effect & Inhibitory & & No effect & No effect \\
\hline
\end{tabular}


sulfates are also present in the subplate of the developing telencephalon where they may mark a preferential pathway for the growth of developing thalamocortical axons (Bicknese et al., 1994). Although KS accounts for only a small fraction of the total GAGs in the developing brain (Werz et al., 1985a; Oohira et al., 1986; Margolis and Margolis, 1989), it is enriched in several midline structures that are thought to act as barriers to growing axons (Steindler and Cooper, 1987; Snow et al., 1990b; Steindler et al., 1990; reviewed in Steindler, 1993). Similarly, in the developing PNS, CS6 and KS mark tissues such as the perinotochordal mesenchyme that act as barriers to the growth of motor and sensory axons (Oakley and Tosney, 1991; Perris et al., 1991). Thus, while KS may be associated with tissues that are nonpermissive for neurite extension, the chondroitin sulfates are associated with tissues through which axons grow as well as with tissues that axons avoid.

The observation that CS GAGs are associated with potential barrier tissues in the PNS but with growth permissive tissues in the CNS prompted us to evaluate the growth modulatory effects of GAGs under two different substrate conditions. Laminin is a major component of the ECM and is a potent promoter of neurite extension in vitro (Lander et al., 1983; Manthorpe et al., 1983; Edgar et al., 1984; Adler et al., 1985). Laminin is abundant in the peripheral tissues through which motor, sensory and sympathetic axons grow (Chui and Sanes, 1984; Rogers et al., 1986). Within the developing CNS, however, only small amounts of laminin have been detected. Laminin-like immunoreactivity is found transiently in the developing telencephalon (Hunter et al., 1992), optic nerve (McLoon ct al., 1988), and hippocampus (Gordon-Weeks et al., 1989) as well as in some developing fiber tracts (Letourneau et al., 1988). This failure to find abundant laminin in the developing CNS may reflect limitations of the currently available reagents since several isoforms of laminin have been identified (Hunter et al., 1989; Ehrig et al., 1990), one of which, merosin, may be abundant in the CNS (Engvall et al., 1991). Both central and peripheral neurons bind to laminin via their heterodimeric integrin receptors (Gehlsen et al., 1988; Ignatius and Reichardt, 1988; Tomaselli et al., 1988; Hall et al., 1990; Sonnenberg et al., 1990). Integrin binding to laminin leads to an activation of protein kinase $\mathrm{C}$ whose enhanced activity is prerequisite for neurite extension (Bixby, 1989).

The L1 glycoprotein, a member of the immunoglobulin super family of cell adhesion molecules, is abundant in both the central and peripheral nervous systems. Like laminin, it is also a potent promoter of neurite growth in vitro (Lagenauer and Lemmon, 1987; Lemmon et al., 1989) and is thought to mediate axonaxon interactions such as fasciculation (Stallcup and Beasley, 1985; Rathjen et al., 1987). Although L1 was originally characterized as a homophilic cell adhesion molecule (Lemmon et al., 1989), heterophilic ligands for L1 have been identified (Kadmon et al., 1990a,b; Kuhn et al., 1990; Felsenfield et al., 1994). L1 binding also leads to an activation of cellular second messenger systems (Schuch et al., 1989; von Bohlen und Halbach et al., 1992; Walsh and Doherty, 1992). The L1-activated second messenger systems, which differ than those activated by integrin-laminin interactions, are complex and include changes in intracellular calcium levels, changes in cytoplasmic $\mathrm{pH}$ and the turnover of inositol phosphates (Schuch et al., 1989, von Bohlen und Halbach et al., 1992; Walsh and Doherty, 1992). Recently, a role for the $s r c$ tyrosine kinase in the response of cerebellar granule neurons to $\mathrm{L} 1$ but not to laminin has been suggested (Ignelzi et al., 1994). By analyzing the effects of GAGs on the growth of neurites from populations of developing central and peripheral neurons on two different substrates, our studies have revealed previously unrealized complexities in the actions of GAGs on the growth of developing neurons. The ability of CS and KS GAGs to inhibit neurite growth on laminin but not on L1 surfaces is likely a reflection of the ability of these two neurite growth promoting molecules to activate different intracellular signaling systems.

Of the five GAGs tested, CS4, CS6, and KS inhibited the growth of both cerebellar and DRG neurons on laminin substrates. Inhibition on laminin-coated substrates was near maximal when these GAGs were used at a concentration of $10 \mu \mathrm{g} /$ $\mathrm{ml}$. Assuming that (1) the average molecular weight of the GAG polymers used is between $20-40,000$ daltons and (2) the efficiency of the adsorption of the GAGs to the substrates was between $65-80 \%$ (see Materials and Methods), these GAGs are active at submicromolar concentrations. Although HS and DS were also capable of inhibiting neurite growth from cerebellar neurons on laminin, inhibition by HS required 100-fold higher concentrations. Dermatan sulfate was intermediate in the strength of its inhibitory action in that statistically significant inhibition occurred when this GAG was used at $50-100 \mu \mathrm{g} / \mathrm{ml}$. At these concentrations, the high density of negative charges added to the substrates may contribute to the growth inhibition observed. The ability of CS4, CS6, and KS to inhibit neurite growth at low concentrations suggests that these effects are mediated by mechanisms other than those dependent on charge density alone.

Throughout the experiments reported here, we used laminin at a concentration of $2 \mu \mathrm{g} / \mathrm{ml}$. When used at this concentration, the mean length of neurites was $90 \%$ of the maximum achieved on substrates coated with higher concentrations of laminin (Dou and Levine, 1994). As the concentration of laminin used to coat surfaces is decreased, neurite length also decreases. However, a reduction in the mean neurite length of $40 \%$ (a value comparable to the degree of inhibition caused by CS4, CS6, and KS) occurred only when laminin was used at a concentration of 0.2 $\mu \mathrm{g} / \mathrm{ml}$ (Dou and Levine, unpublished observations). As the data in Figure $1 B$ precludes the possibility that the GAGs are reducing the amount of laminin bound to the substrate, the growth inhibition reported here must be due to some specific action of the GAGs per se rather than a reduction in substrate-bound laminin.

In the case of the L1 glycoprotein, CS4, CS6, DS, and HS all reduced the amount of substrate bound L1 in a dose-dependent manner. When the GAGs were used at a concentration of $1 \mathrm{mg} /$ $\mathrm{ml}$, this reduction was as high as $50-60 \%$. Although this data suggests that the growth inhibition caused by DS and HS may be due to a reduction in the amount of L1 bound to the PLLcoated surfaces, the following observations rule out this possibility. First, although CS4, CS6, DS, and HS were equally effective in reducing the amount of $\mathrm{L} 1$ bound to the substrates, HS and DS inhibited neurite extension from cerebellar neurons whereas CS4 and CS6 did not. The data in Figure 2 also eliminate the possibility that CS4 and CS6 were not incorporated into the substrate. Second, when cerebellar neurons were plated onto surfaces coated with $\mathrm{Ll}$ at a concentration of $1 \mu \mathrm{g} / \mathrm{ml}$, a value comparable to the amount of substrate-bound L1 detected after coating surfaces with mixtures of Ll and GAGs at a concentration of $1 \mathrm{mg} / \mathrm{ml}$, the mean neurite length was approximately $85 \mu \mathrm{m}$, a value that is only $11 \%$ reduced from control values. Thus, the ability of HS and DS, at moderate concentra- 
tions, to inhibit the growth of cerebellar neurons on L1 surfaces is not due to a reduction in substrate-bound $\mathrm{Ll}$, rather, it is likely due to a specific interaction between the GAGs and L1 or between the substrate bound GAGs and the neurons. If the interactions are between the GAGs and the neurons, there must be a spccificity to the manner in which different types of neurons respond to substrate bound GAGs as the growth of DRG neurons was not inhibited under conditions that inhibit neurite growth from cerebellar neurons.

We can only speculate regarding the mechanisms by which GAGs exert their growth inhibitory effects. One possibility is that the inhibitory GAGs interact with laminin/L1 in a manner such that the neurite promoting domains of the molecules are inaccessible to the neurons. Detailed analyses of laminin using either proteolytic fragments or synthetic peptides have identified several different structural domains that promote cell adhesion and neurite outgrowth in vitro (Edgar et al., 1984; Aumailley et al., 1987; Goodman et al., 1987; Skubitz et al., 1991). Some of these fragments and peptides bind heparin with high affinity (Edgar et al., 1984; Skubitz et al., 1991). The binding of GAGs other than heparin to either intact laminin, proteolytic fragments of laminin or synthetic laminin-derived peptides has not been demonstrated. Thus, it is unlikely that those GAGs with growth inhibitory activity (i.e., CS4, CS6, and KS) are exerting their inhibitory actions through interactions with specific domains of laminin. The lack of any significant effect of heparan sulfate on neurite growth from either cerebellar or DRG neurons on laminin surfaces suggests that either heparan sulfate is not functionally equivalent to heparin or that heparan sulfate binding to laminin does not sterically hinder cellular integrins' access to those domains of laminin that promote neurite extension.

It is not yet known whether there are specific molecular interactions between GAGs and the L1 glycoprotein such as those occurring between some proteoglycan core proteins and L1 (Grumet et al., 1993; Friedlander et al., 1994). The ability of HS and DS to inhibit neurite extension from cerebellar neurons on Ll-coated surfaces suggests that such interactions may indeed be taking place although we cannot rule out the possibility that these GAGs are altering the neuronal surface membrane in a manner that prevents L1 from interacting with either its homophilic or heterophilic binding partners whether in cis (Kadmon et al., 1990a,b) or in trans (Kuhn et al., 1990; Felsenfield et al., 1994).

As there is little direct experimental support for a steric hindrancc model of GAG action, we suggest that the inhibitory actions of CS4, CS6, and KS on neurite growth on laminin are due to effects of the GAGs on the neurons themselves. In such a model of GAG action, substrate bound GAGs interact with specific GAG binding proteins that act as receptors for these extracellular ligands. These putative receptors might be linked to cellular second messenger systems such that one consequence of this receptor-ligand interaction would be an interference or dampening of the integrin-dependent activation of $\mathrm{C}$ kinase (Bixby, 1989). This alteration in the activation state of $\mathrm{C}$ kinase or other second messenger systems would change the neuronal physiology such that neurite elongation is inhibited or proceeds at a slower rate. Such a receptor-ligand model of GAG action could also account for the lack of any significant effect of CS6 and KS on neurite growth from both cerebellar and DRG neurons on L1-coated surfaces. L1-mediated axon growth is likely to involve different intracellular second messenger systems than does growth on laminin substrates (Bixby and Jhabvala, 1992;
Ignelzi et al., 1994). Glycosaminoglycan binding to cell surface receptor sites may not interfere with the activation of $\mathrm{G}$ proteins or the changes in intracellular calcium levels or $\mathrm{pH}$ that follow from $\mathrm{L} 1$ activation. In this manner, an array of cellular GAG receptors with different binding specificities and patterns of cellular expression each linked differentially to intracellular signaling mechanisms would provide for the specificity of GAG action reported here and the ability of some GAGs to inhibit laminin-mediated growth without inhibiting L1-mediated growth while other GAGs inhibit L1-mediated neurite growth without effecting laminin-mediated growth.

There is increasing evidence for cell surface binding sites for extracellular GAGs, in particular heparin and HS. First, macrophages appear to have cell surface receptors for heparin whose activation increases the secretion of urokinase-type plasminogen activator (Falcone, 1989). Second, when either GAGs or synthetic GAG-like carbohydrates are added to the medium in which mesencephalic neurons are growing, the GAGs bind to the cell surface in a specific and saturable manner and are subsequently internalized (Lafont et al., 1992, 1994). In this system, soluble GAGs, particularly CS4 and CS6, promote axonal and dendritic growth (Lafont et al., 1992, 1994). Third, heparin and HS bind with high affinity to a site close to the amino terminal of the neuronal cell adhesion molecule NCAM (Cole et al., 1986). Thus it is possible that some of the growth inhibitory actions of GAGs reported here are due to a direct interaction between the GAGs and the target neurons.

In vivo, elongating axons reproducibly avoid certain cells and tissues. For example, in the chick, developing sensory and motor axons avoid the posterior somite, perinotochordal mesenchyme and the precursor of the pelvic girdle (Tosney and Oakley, 1990). In the developing CNS, spinal axons do not cross the dorsal midline and fibers of the optic nerve do not cross the midline of the optic tectum (Snow et al., 1990b). It has been suggested that these specialized areas can be considered barriers to axonal growth (for review, see Steindler, 1993). Peanut lectin binding glycoproteins and several GAGs, particularly CS6 and $\mathrm{KS}$, are molecular markers for these barrier tissues (Steindler and Cooper, 1987; Snow et al., 1990b; Steindler et al., 1990; Cole and McCabe, 1991; Oakley and Tosney, 1991) and CS and $\mathrm{KS}$ have been shown to inhibit axon growth in vitro (Carbonetto et al., 1983; Snow et al., 1990a; Cole and McCabe, 1991). The data presented here demonstrating a cellular and a substrate specificity to the growth inhibitory properties of isolated GAGs suggests that caution must be used in extrapolating the results of in vitro studies to the behavior of growing axons in vivo. In cases where an axon is elongating on surfaces containing the $\mathrm{Ll}$ glycoprotein, GAGs may have only minor inhibitory effects on axon growth and could even enhance the rate of elongation. On the other hand, the elongation of axons growing in an environment rich in laminin may be quite sensitive to moderate levels of GAGs in their pathway.

\section{References}

Adler R. Jerden J, Hewitt AT (1985) Responses of cultured neural retinal cells to substratum-bound laminin and other extracellular matrix molecules. Dev Biol 112:100-114.

Akeson R, Warren SL (1986) PC 12 adhesion and neurite formation on selected substrates are inhibited by some glycosaminoglycans and a fibronectin-derived tetra peptide. Exp Cell Res 162:347-362.

Aumailley M, Nurcombe V, Edgar D, Paulsson M, Timpl R (1987) The cellular interactions of laminin fragments: cell adhesion correlates 
with two fragments-specific high affinity binding sites. J Biol Chem 262:11532-11538.

Avnur Z, Geiger B (1984) Immunocytochemical localization of native chondroitin-sulfate in tissues and cultured cells using specific monoclonal antibody. Cell 38:811-822.

Bicknese AR, Sheppard AM, O'Leary DDM, Pearlman AL (1994) Thalamocortical axons extend along a chondroitin sulfate proteoglycan-enriched pathway coincident with the neocortical subplate and distinct from the efferent path. J Neurosci 14:3500-3510.

Bixby JL (1989) Protein kinase $\mathrm{C}$ is involved in laminin stimulation of neurite outgrowth. Neuron 3:287-297.

Bixby JL, Jhabvala P (1992) Inhibition of tyrosine phosphorylation potentiates substrate-induced neurite growth. J Ncurobiol 23:468480.

Carbonetto S, Gruver MM, Turner DC (1983) Nerve fiber growth in culture on fibronectin, collagen, and glycosaminoglycan substrates. J Neurosci 3:2324-2335.

Caroni P, Schwab ME (1988) Two membrane protein fractions from rat central myelin with inhibitory properties for neurite growth and fibroblast spreading. J Cell Biol 106:1281-1288.

Chui AY, Sanes IR (1984) Differentiation of basal lamina in synaptic and extrasynaptic portions of embryonic rat muscle. Dev Biol 103: $456-467$.

Colamarino SA, Tessier-Lavigne M (1995) The axonal chemoattractant netrin- 1 is also a chemorepellent for trochlear motor axons. Cell 81: $621-629$.

Cole GJ, McCabe CF (1991) Identification of a developmentally regulated keratan sulfate proteoglycan that inhibits cell adhesion and neurite outgrowth. Neuron 7:1007-1018.

Cole GJ, Loewy A, Cross NV, Akeson R, Glaser L (1986) Topographic localization of the heparin-binding domain of the neural cell adhesion molecule N-CAM. J Cell Biol 103:1739-1744.

Davies JA, Cook GMW, Stern CD, Keynes RJ (1990) Isolation from chick somites of a glycoprotein fraction that causes collapse of dorsal root ganglion growth cones. Neuron 4:11-20.

Dodd J, Morton SB, Karagogeos D, Yamamoto M, Jessell TM (1988) Spatial regulation of axonal glycoprotein expression on subsets of embryonic spinal neurons. Neuron 1:105-116.

Dou CL, Levine JM (1994) Inhibition of neurite growth by the NG2 chondroitin sulfate proteoglycan. J Neurosci 14:7616-7628.

Edgar D, Timpl R, Thoenen $\mathrm{H}$ (1984) The heparin-binding domain of laminin is responsible for its effects on neurite outgrowth and neuronal survival. EMBO J 3:1463-1468.

Ehrig K, Leivo I, Argraves WS, Ruoslahti E, Engvall E (1990) Merosin, a tissue-specific basement membrane protein, is a laminin-like protein. Proc Natl Acad Sci USA 87:3264-3268

Engvall E, Earwicker D, Manthorpe M, Varon S, Hogg T (1991) Merosin but not laminin is expressed in the mammalian CNS. Soc Neurosci Abstr 17:208.

Faissner A, Kruse J, Nieke J, Schachner M (1984) Expression of neural cell adhesion molecule L1 during development in neurological mutants and in the peripheral nervous system. Dev Brain Res 15:69-82.

Faissner A, Clement A, Lochter A, Streit A, Mandl C, Schachner M (1994) Isolation of a neural chondroitin sulfate proteoglycan with neurite outgrowth promoting properties. J Cell Biol 126:783-799.

Falcone DJ (1989) Heparin stimulation of plasminogen activator secretion by macrophage-like line, RAW 264.7. J Cell Physiol 140: 219-226.

Felsenfeld DP, Hynes MA, Skoler KM, Furley AJ, Jessel TM (1994) TAG 1 can mediate homophilic binding, but neurite outgrowth on TAG-1 requires an L1-like molecule and $\beta 1$ integrins. Neuron 12: 675-690.

Fitzgerald M, Kwial GC, Middleton J, Pini A (1993) Ventral spinal cord inhibition of neurite outgrowth from embryonic rat dorsal root ganglia. Development 117:1377-1384.

Flaccus A, Janetzko A. Tekotte H, Margolis RK, Margolis RU (1991) Immunocytochemical localization of chondroitin and chondroitin 4and 6-sulfates in developing rat cerebellum. J Neurochem 56:16081615 .

Friedlander DR, Milev P, Karthikeyan L, Margolis RK, Margolis RU, Grumet M (1994) The neuronal chondroitin sulfate proteoglycan neurocan binds to the neural cell adhesion molecules Ng-CAM/L1/ NILE and N-CAM, and inhibits neuronal adhesion and neurite outgrowth. J Cell Biol 125:669-680.

Furley AJ, Morton SB, Manalo D, Karagogeos D, Dodd J, Jessel TM
(1990) The axonal glycoprotein TAG-1 is an immunoglobulin superfamily member with neurite outgrowth-promoting activity. Cell 61:157-170.

Gehlsen K, Engvall E, Ruoslahti E (1988) The human laminin receptor is a member of the integrin family of cell adhesion receptors. Science 241:1228-1229.

Geisert EE, Bidanset DJ (1993) A central nervous system keratan sulfate proteoglycan: localization to boundaries in the neonatal brain. Dev Brain Res 75:163-173.

Goodman CS, Shatz. C.I (1993) Developmental mechanisms that generate precise patterns of neuronal connectivity. Neuron 10(Suppl):7798.

Goodman S, Deutzmann R, von der Mark K (1987) Two distinct cell binding domains in laminin can independently promote nonneuronal cell adhesion and spreading. J Cell Biol 105:589-598.

Gordon-Weeks PR, Giffin N, St E Weeks C, Barben C (1989) Transient expression of laminin immunoreactivity in the developing rat hippocampus. J Neurocytol 18:451-463.

Grumet M, Flaccus A, Margolis RU (1993) Functional characterization of chondroitin sulfate proteoglycans of brain: interactions with neurons and neural cell adhesion molecules. J Cell Biol 120:815-824.

Hall DE, Reichardt LF, Crowley E, Holley B, Moezzi H, Sonnenberg A, Damsky CH (1990) The $\alpha 1 / \beta 1$ and $\alpha 6 / \beta 1$ integrin heterodimers mediate cell attachment to distinct sites on laminin. J Cell Biol 110: $2175-2184$

Hardingham TE, Fosang AJ (1992) Proteoglycans: many forms and many funclions. FASEB J 6:861 -870.

Hatten ME (1985) Neuronal regulation of astroglial morphology and proliferation in vitro. J Cell Biol 100:384-396.

Hunter DD, Shah V, Merlie JP, Sanes JR (1989) A laminin-like adhesive protein concentrated in the synaptic cleft of the neuromuscular junction. Nature 338:229-234.

Hunter DD, Llinas R, Ard M, Merlie JP, Sanes JR (1992) Expression of S-laminin and laminin in the developing central nervous system. J Comp Neurol 323:238-251

Ignatius MJ, Reichardt LF (1988) Identification of a neuronal laminin receptor: a $\mathrm{Mr} 200 \mathrm{~K} / 120 \mathrm{~K}$ integrin heterodimer that binds laminin in a divalent cation-dependent manncr. Neuron 1:713-725.

Ignelzi MA, Miller DR, Soriano P, Manes PF (1994) Impaired neurite outgrowth of src-minus cerebellar neurons on the cell adhesion molecule L1. Neuron 12:873-884.

Jackson RL, Busch SJ, Cardin AD (1991) Glycosaminoglycans: molecular properties, protein interactions, and role in physiological processes. Physiol Rev 71:481-539.

Kadmon G, Kowitz A, Altevogt P, Schachner M (1990a) The neural cell adhesion molecule N-CAM enhances L1-dependent cell-cell interactions. J Cell Biol 110:193-208.

Kadmon G, Kowitz A, Altevogt P, Schachner M (1990b) Functional cooperation between the neural cell adhesion molecules $\mathrm{L} 1$ and N-CAM is carbohydrate dependent. J Cell Biol 110:209-218.

Kennedy TE, Serafini T, de la Torre JR, Tessier-Lavigne M (1994) Netrins are diffusible chemotropic factors for commissural axons in the embryonic spinal cord. Cell 78:425-435.

Keynes RJ, Cook GMW (1995) Repulsive and inhibitory signals. Curr Opin Neurobiol 5:75-82.

Kolodkin AL, Matthes DJ, Goodman CS (1993) The semaphorin genes encode a family of transmembrane and secreted growth cone guidance molecules. Cell 75:1389-1399.

Kuhn TB, Stoeckli ET, Condrau MA, Rathjen FG, Sonderegger P (1991) Neurite outgrowth on immobilized axonin-1 is mediated by a heterophilic interaction with L1 (G4). J Cell Biol 115:1113-1126.

Lafont F, Rouget M, Triller A, Prochiantz A, Rousselet A (1992) In vitro control of neuronal polarity by glycosaminoglycans. Development 114:17-29.

Lafont F, Prochiantz A, Valenza C, Petitou M, Pascal M, Rouget M, Rousselet A (1994) Defined glycosaminoglycan motifs have opposite effects on neuronal polarity in vitro. Dev Biol 165:453-468.

Lagenaur C, Lemmon V (1987) An L1-like molecule, the 8D9 antigen is a potent substrate for neurite extension. Proc Natl Acad Sci USA 84:7753-7757.

Lander AD, Tomaselli K, Calof AL, Reichardt LF (1983) Studies on extracellular matrix components that promote neurite outgrowth. Cold Spring Harbor Symp Quant Biol 48:611-623.

Lcmmon V, Farr KL, Lagenaur C (1989) L1 mediated axon outgrowth occurs via a homophilic binding mechanism. Neuron 2:1597-1603. 
Lemmon V, Burden SM, Payne HR, Elmslie GJ, Hlavin ML (1992) Neurite outgrowth on different substrates: permissive versus instructive influences and the role of adhesive strength. J Neurosci 12:818826.

Letouneau PC, Madsen AM, Palm SL, Furcht LT (1988) Immunoreactivity for laminin in the developing ventral longitudinal pathway of the brain. Dev Biol 125:135-144.

Lochter A, Vaughan L, Kaplony A, Prochiantz A, Schachner M, Faissner A (1991) J1/tenascin in substrate-bound and soluble form displays contrary effects on neurite outgrowth. J Cell Biol 113:11591171.

Luo Y, Raible D, Raper JA (1993) Collapsin: a protein in brain that induces the collapse and paralysis of neuronal growth cones. Cell 75: 217-227.

MacSween JM, Eastwood SL '(1978) Recovery of immunologically active antigen from staphylococcal protein A-antibody adsorbent. J Immunol Methods 23:259-267.

Manthorpe M, Engvall E, Ruoslahti E, Longo FM, Davis GE, Varon S (1983) Laminin promotes neuritic regeneration from cultured peripheral and central neurons. J Cell Biol 97:1882-1890.

Margolis RU, Margolis RK (1989) Nervous tissue proteoglycans. Dev Neurosci 11:276-288.

Margolis RU, Margolis RK, Chang LB, Preti C (1975) Glycosaminoglycans of brain during development. Biochem 14:85-88.

McLoon SC, McLoon LK, Palm SI, Furcht LT (1988) Transient expression of laminin in the optic nerve of the developing rat. J Neurosci 8:1981-1990

Oakley RA, Tosney KA (1991) Peanut agglutinin and chondroitin-6sulfate are molecular markers of tissues that act as barriers to axon advance in the avian embryo. Dev Biol 147:187-206.

Oohira A, Matsui F, Matsuda M, Shoji R (1986) Developmental changes in the glycosaminoglycan composition of the rat brain. $\mathrm{J}$ Neurochem 47:588-593.

Oohira A, Matsui F, Katoh-Semba R (1991) Inhibitory effects of brain chondroitin sulfate proteoglycans on neurite outgrowth from PC12D cells. J Neurosci 1 1:822-827.

Patterson PH (1988) On the importance of being inhibited, or saying no to growth cones. Neuron 1:263-267.

Payne HR, Burden SM, Lemmon V (1992) Modulation of growth cone morphology by substrate-bound adhesion molecules. Cell Motil Cytoskeleton 21:65-73.

Perris R, Krotoski D, Lallier T, Domingo C, Sorrel JM, Bronner-Fraser M (1991) Spatial and temporal changes in the distribution of proteoglycans during avian neural crest development. Development 111: 583-599.

Pini A (1993) Chemorepulsion of axons in the developing mammalian central nervous system. Science 261:95-98

Rathjen FG, Wolff JM, Frank R, Bonhoeffer F, Rutishauser U (1987) Membrane glycoproteins involved in neurite fasciculation. J Cell Biol 104:343-353

Rogers SL, Edson KL, Letourneau PC, McLoon SC (1986) Distribution of laminin in the developing peripheral nervous system of the chick. Dev Biol 113:429-435.

Rutishauser U, Jessell TM (1988) Cell adhesion molecules in vertebrate neural development. Physiol Rev 68:819-857.

Sanes JR (1989) Extracellular matrix molecules that influence neural development. Annu Rev Neurosci 12:491-516.

Schuch U, Lohse MJ, Schachner M (1989) Neural cell adhesion molecules influence second messenger systems. Neuron 3:13-20.
Serafini T, Kennedy TE, Galko MJ, Mirtzayan C, Jessell TM, TessierLavigne M (1994) The netrins define a family of axon outgrowthpromoting proteins homologous to C. elegans UNC-6. Cell 78:409424.

Skubitz APN, Letourneau PC, Wayner E, Furcht LT (1991) Synthetic peptides from the carboxyl-terminal globular domain of the A chain of laminin: their ability to promote cell adhesion and neurite outgrowth, and interact with heparin and the $\beta 1$ integrin subunit. $J$ Cell Biol 115:1137-1148.

Snow, DM, Lemmon, V, Carrino, DA, Caplan, AI, Silver, J (1990a) Sulfated proteoglycans in astroglial barriers inhibit neurite outgrowth in vitro. Exp Neurol 109:111-130.

Snow DM, Steindler DA, Silver J (1990b) Molecular and cellular characterization of the glial roof plate of the spinal cord and optic tectum: a possible role for a proteoglycan in the development of an axon barricr. Dev Biol 138:359-376.

Sonnenberg A, Linders CJT, Modderman PW, Mansky CH, Aumailley M (1990) Integrin recognition of different cell binding fragments of laminin (P1, E3, E8) and evidence that $\alpha 6 / \beta 1$ but not $\alpha 6 / \beta 4$ functions as a major receptor for E8. J Cell Biol 110:2145-2155.

Stallcup WB, Beasley L (1985) Involvement of the nerve growth factor-inducible large external glycoprotein (NILE) in neurite fasciculation in primary culture of rat brain. Proc Natl Acad Sci USA 82 $1276-1280$

Stallcup WB, Beasley L, Levine JM (1985) Antibody against nerve growth factor-inducible large external (NILE) glycoprotein labels nerve fiber tracts in the developing rat nervous system. J Neurosci 5:1090-1101.

Steindler DA (1993) Glial boundaries in the developing nervous system. Annu Rev Neurosci 16:445-470.

Steindler DA, Cooper NGF (1987) Glial and glycoconjugate boundaries during postnatal development of the central nervous system. Dev Brain Res 36:27-38.

Steindler DA, O'Brien TF, Laywell E, Harrington K, Faissner A, Schachner M (1990) Boundaries during normal and abnormal brain development: in vivo and in vitro studies of glial and glycoconjugates. Exp Neurol 109:35-56.

Tomaselli KJ, Damsky CH, Reichardt LF (1988) Purification and characterization of mammalian integrins expressed by a rat neuronal cell line (PC12): evidence that they function as $\alpha / \beta$ receptors for collagen IV and laminin. J Cell Biol 107:1241-1252.

Tosney KW, Oakley RA (1990) The perinotochordal mesenchyme acts as a barrier to axon advance in the chick embryo: implications for a gencral mechanism of axonal guidance. Exp Neurol 109:75-89.

Verna JM, Fichard A, Saxod R (1989) Influence of glycosaminoglycans on neurite morphology and outgrowth patterns in vitro. Int $\mathrm{J}$ Dev Neurosci 7:389-399.

von Bohlen und Halbach F, Taylor J, Schachner M (1992) Cell typespecific effects of the neural adhesion molecules L1 and N-CAM on diverse second messenger systems. Eu J Neurosci 4:896-909.

Walsh FS, Doherty P (1992) Second messengers underlying cell-contact-dependent axonal growth stimulated by transfected N-CAM, N-cadherin, or L1. Cold Spring Harbor Symp Quant Biol 57:431440.

Werz W, Fischer G, Schachner M (1985a) Glycosaminoglycans of rat cerebellum. I. Quantitative analysis of the main constituents at postnatal day 6. J Neurochem 44:900-906.

Werz W, Fischer G, Schachner M (1985b) Glycosaminoglycans of rat cerebellum. II. A developmental study. J Neurochem 44:907-910. 